\title{
Comparative Study of Biodegradation and Coagulation of Dairy Effluent by Using Immobilized Microbial Isolates and Chitosane Silver Nano Particles and Production Biodiesel
}

\author{
Mohammed Taha Moustafa*
}

National Water Research Center-Central Laboratory for Environmental Quality Monitoring, Egypt

\section{Introduction}

Environmental pollution is one of the major ecological difficulties, rapid growth of industrial and explosion of population are the primary reasons for the dwindling water quality [1]. In last few decades, requiring urgent attention has been paid to the industrial wastes, which are usually discharged harmful and toxic substances into on land or into different natural water sources such as rivers and canals and creating health hazards [2]. Milk processing requires high specific water consumption and considerable raw material waste effluents [3]. Dairy industry is one of the major industries causing water pollution because it contains large quantities of milk constituents such as casein, lactose, inorganic salt, detergents, dissolved sugars and proteins, fats, rich in fats, oils and greases and can have negative impacts on wastewater treatment systems [4]. The dairy industries produce effluents as often cause foul odours, blockage of pipes and sewer lines $[5,6]$. When dairy effluents discharged into water bodies, these effluents rapidly degraded causing depletion of dissolved oxygen levels of receiving water bodies. These receiving water bodies then become a propagation place for flies and mosquitoes carrying malaria and other perilous disease like dengue fever, yellow fever and chicken [5]. The disposal of large quantities of this wastewater untreated or partially treated and domestic source rapidly causes deterioration of the environment [7]. Environmentalists and governments are looking for efficient, cheap and long lasting solutions for waste treatment and recycling. Chemical methods of wastewater treatment are inevitably cost intensive and cannot be employed in all industries, and these methods creates waste disposable problems by using neutralization and detoxification of the discharged wastewater is necessary which also causes further contaminations to the environment $[8,9]$. To overcome the shortage of chemical treatment, studies have been conducted using microorganisms for the biological industrial waste biological treatment offers an economical alternative to chemical treatment method as they are highly selective to the range of pollutants removed and are expensive. Microbial treatment systems have advantage of being simple in design and low in cost [10]. Fungi and bacteria are concerned in the biodegradation of undesirable materials or compounds and convert them into beneficial products [11]. The development of applications for a chitosan has expanded rapidly in recent years. Chitosan is a naturally available biopolymer coagulant, and it considers safe and more economical alternative for developing countries. Extraction of chitosan from fish waste is gaining significant importance in the world of industrial. Chitosan is a naturally available biopolymer of glucosamine and $\mathrm{N}$-acetyl glucosamine. It has been produced by alkaline $\mathrm{N}$-deacetylation process of shrimp (Crangon) and fish (Labeorohita). Chitosan, being polycationic, nontoxic, coagulation creates better quality flocks, have a faster settling velocity, biodegradable as well as antimicrobial, has many applications especially in the agriculture, food and pharmaceutical industries and wastewater treatment [12-14]. Use eco-friendly such as chitosan belonging to the polysaccharide to use as reducing and stabilizing agent to obtain metal nanostructures [15]. Chitosan nano silver generally showed stronger bactericidal effects for gram positive bacteria (E. faecalis and Staphylococcus aureus) than for a gram-negative bacteria (E. coli, Salmonella typhimurium and K. pneumoniae) $[16,17]$. One of the most eminent renewable energy resources is biodiesel and considered to be a potential alternative to petro-diesel fuel in many developed and developing countries worldwide [18]. The global biodiesel production has increased to $\mathbf{1 8 . 2}$ billion liters per year from 2000 to 2010 [19]. Oleaginous microbes, known for their ability to yield $20 \%$ to $87 \%$ of their total biomass as lipids and fatty acids $[20,21]$. Microbial oils when compared to plant oils were found to be more economical and easier for this processed.

*Corresponding author: Mohammed Taha Moustafa, National Water Research Center-Central Laboratory for Environmental Quality Monitoring, El-Qanater, Qalubiya, 13621/6 Cairo, Egypt

Accepted: June 10, 2019

Published online: June 12, 2019

Citation: Moustafa MT (2019) Comparative Study of Biodegradation and Coagulation of Dairy Effluent by Using Immobilized Microbial Isolates and Chitosane Silver Nano Particles and Production Biodiesel. Ann Microbiol Res 3(1):61-75 
Citation: Moustafa MT (2019) Comparative Study of Biodegradation and Coagulation of Dairy Effluent by Using Immobilized Microbial Isolates and Chitosane Silver Nano Particles and Production Biodiesel. Ann Microbiol Res 3(1):61-75

Currently, much attention is being paid to the development of microbial lipids can represent a valuable alternative feedstock for biodiesel production, for many advantages such as short life cycle, microorganisms grows much faster and are easier to bandle, less work required, are less affected by the location, season, climate, as well as faster growth and a potential solution for a bio-based economy [22]. In the future, production of microbial lipid will become a major oil source in the transportation sector $[23,24]$. Oleaginous micro-organisms such as yeasts, fungi and micro algae can accumulate high amounts of reserved lipids in the form of triacylglycerols under appropriate cultivation condition $[25,26]$. The biodiesel quality depends upon the fatty acid composition of the oil feedstock [27]. Biodiesel constitutes a renewable fuel that is convenient with current commercial diesel engines and has clear benefits relative to diesel fuel including enhanced biodegradation, decreased toxicity, and a lower emission profile [28]. To reduce the cost of microbial oils, exploring other carbon sources instead of glucose is very important especially for such oils applied to biodiesel production. It was reported that xylose, corn straw, molasses, whey and other agricultural and industrial wastes could be used as the carbon sources for microbial oils accumulation [19]. Oleaginous fungi can synthesizes and accumulate high amounts of Triacylglycerols (TAG) within their cells. This TAG can be effectively changed over to biodiesel through a method know as transesterification via the conversion of TAG and methanol with potassium hydroxide as a catalyst [29]. Many researches such as yeast strains Curvularia sp. [23] and Trichoderma reesei has a wide spectrum in production of biodiesel [21], also Trichoderm spp. and Gliocladium roseum [30].

\section{Objective}

- The purpose of the study is to compare the reduction rate of $B O D, C O D$ and turbidity for dairy effluent after the addition of fungal and bacterial to units and using the chitosan as an adsorbent to treat dairy wastewater

- Application of chitosan silver nanocomposites efficiency as a biomaterial for dairy wastewater treatment by coagulation process

- Isolation and identification of fungal isolate capable of yielding high amount of storage lipids.

- Characterization and comparative analysis of fatty acid profiles of novel isolated fungus and ability of the selected isolate on the growth on molasses as a sole carbon source and test their potential utilities as biodiesel feedstock.

\section{Materials and Methods}

\section{Study area}

For the present study the dairy effluent samples were collected from dairy factories Panda milk in Kaliuob City industrial zones, Egypt. Samples were collected in sterile $5 \mathrm{~L}$ plastic container. Samples were stored at $4{ }^{\circ} \mathrm{C}$ inside an ice box then transferred immediately to the laboratory of Central Laboratory for Environmental Quality Monitoring for further experiments.

\section{Characterization physico-chemical analysis of dairy effluent and treated effluent}

All the samples were analyzed for untreated dairy effluent and final filtrated after treatment, according to standard methods for the examination of water and wastewater (APHA, 2012). These parameters include; $\mathrm{pH}$, turbidity, total suspended solids (TSS), biological oxygen demand (BOD), COD and Bacteriology analysis (Total coliform , fecal colifrom, fecal streptococci and pseudomonas aeruginosa).

\section{Coagulation test}

In this research, it is very important to determine the optimum dosage of coagulant and to establish optimum chemical conditions as $\mathrm{pH}$ value. Then, the different efficiencies were chosen for a coagulant and $\mathrm{pH}$ dose for the different coagulants. For chitosane, coagulant dose was selected at 0.5 to $3 \mathrm{~g} / 700 \mathrm{ml}$ and $\mathrm{pH}$ from 6.39 to 6.58 . A conventional jar test apparatus was employed for the test. All tests were carried out with $500 \mathrm{ml}$ of wastewater at room temperature. Optimum $\mathrm{pH}$ was determined by adjusting of $700 \mathrm{ml}$ aliquot of wastewater at different $\mathrm{pH}$ using sulfuric acid and sodium hydroxide. A fast stirring of $100 \mathrm{rpm}$ was applied for 3 minutes. At the end of the speed period, the mixing was stopped and the formed flocs were left to settle down for 30 minutes. The samples to be tested were taken from the top of the water level in the flask.

\section{Isolation of microorganisms}

To count the number of bacteria and fungal colonies in the Wastewater, serial dilution followed with pour plating was done. Three samples were prepared after serial dilution to $1 / 10,1 / 100,1 / 1000,1 / 10000$ and from each sample one $\mathrm{ml}$ sample is poured into flask contain Sabouraud's Glucose broth medium and is well mixed and incubated at $28{ }^{\circ} \mathrm{C}$ for 72 hours. Similar in bacteria one $\mathrm{ml}$ sample is poured into flask of Nutrient broth and incubated at $35^{\circ} \mathrm{C}$ for $24 \mathrm{~h}$. One loopful enriched sample from N.B. flask was streaked on Nutrient Agar plates and skim milk agar. One loopful enriched sample from S.B. was streaked on Sabouraud's Agar plates. Nutrient Agar plates were incubated at $35^{\circ} \mathrm{C}$ for $24 \mathrm{~h}$, while the Sabouraud's Agar plates were incubated for 3 days at 28 ${ }^{\circ} \mathrm{C}$. Plating was done in triplicate for each medium. Isolated colonies were further studied for Gram's staining and identified on the basis of Gram nature.

\section{Identification and phylogenetic analysis}

Lactobacillus isolate was identified using Biolog's microbial identification system (Biolog ${ }^{\circ}$ Gen III,USA). While $M$. circinelloides was identified depending on colony morphology and microscopic examination using lactophenol cotton blue staining method.

Identification of the $M$. circinelloides was performed based on molecular genetic analysis using the internal transcribed spacer region using ITS1-5.8S ITS2 regions by specific primers ITS1 (5'TCC GTA GGT GAA CCT TGC GG 3') and ITS4 (5'TCC TCC GCT TAT TGA TAT GC 3'). Partial sequences of the isolated 18s rDNA were obtain using a strategy based on [31]. 
The nearest fungus with similar sequence was aligned with GenBank database using BLASTn as the query sequence [32]. Alignment with the similar sequences was carried out using ClustalW [15]. Phylogenetic tree was structured applying neighbor-joining algorithm with MEGA 7 software and bootstrap for 1000 re-sampling to ensure robustness and reliability of trees constructed [12].

\section{Experimental procedure for the extraction of chitosan}

Preparation of chitosan from tilapia fish scales was done following three major steps, demineralization, deproteination, and deacetylation. For demineralization, $10 \mathrm{~g}$ of raw fish scales were washed thoroughly with water than was treated with in $1 \% \mathrm{HCL}$ solution for 36 hours at room temperature. After demineralization, the sample was washed with tap water till the sample reaches neutral $\mathrm{pH}$. For deproteination, fish scales powder was treated with $2 \mathrm{~N} \mathrm{NaOH}$ for $36 \mathrm{~h}$. The residue was then collected and washed with distilled water until the $\mathrm{pH}$ became neutral, followed by thorough washing and drying as mentioned above. After this step, the end product was chitin. For deacetylation, chitin was treated with strong alkali, $0.4 \mathrm{~g}$ of chitin was added to $50 \% \mathrm{NaOH}$ for $5 \mathrm{~h}$ at $90^{\circ} \mathrm{C}$ followed by washing till it reaches neutral $\mathrm{pH}$. After drying, the final product recovered was chitosan (Figure 1) [33].

\section{Immobilization of bacteria in alginate beads}

Sodium alginate was used as the immobilizing agent for bead preparation. Exponentially growing cells were harvested by centrifugation ( $4500 \mathrm{rpm}$ for $10 \mathrm{~min}$ ) and resuspended in $50 \mathrm{ml}$ of sterile water. To this, $50 \mathrm{ml}$ of $4 \%$ alginate solution was mixed thoroughly to get a final alginate concentration of $2 \%$. The alginate-bacterial mixture with chitosane then added drop wise into $\mathrm{CaCl}_{2}(0.1 \mathrm{M})$ solution. The beads were kept in the same solution for 30 mins at $4{ }^{\circ} \mathrm{C}$ for hardening.

\section{Immobilization of fungi in alginate beads}

Commercial grade sodium alginate was used as the immobilizing agent for bead preparation. Exponentially growing M. circinelloides, was harvested by centrifugation (4500 rpm for $10 \mathrm{~min}$ ) and resuspended in $50 \mathrm{ml}$ of sterile water. To this, $50 \mathrm{ml}$ of $4 \%$ alginate solution was mixed thoroughly to get a final alginate concentration of $2 \%$. The alginated mixture with fungi was then added drop wise into $\mathrm{CaCl}_{2}(0.1 \mathrm{M})$ solution. The beads were kept in the same solution for $30 \mathrm{~min}$ at $4{ }^{\circ} \mathrm{C}$ for hardening.

\section{Experimental and Design of integrated treatment system}

The sample water which has to be treated will undergo different treatment steps in specially designed parts of the plant is presented in Figure 2. The construction of Wastewater treatment plant consists of six stages, filtration tank, Fungi unite, bacteria unite, coagulation tank and chitosane silver nano particles tank. The first tank was considered as the primary tank capacity $5 \mathrm{~L}$ with $50 \mathrm{~cm}$ height, contain two layers of filtration media were placed, $15 \mathrm{~cm}$ height of black sand on the top, while $15 \mathrm{~cm}$ height of Zeolite was on the bottom than
A: filtration tank
B: bacteria unite
C:fungi unite
D: chitosane tank
E: chitoane Ag nano particles

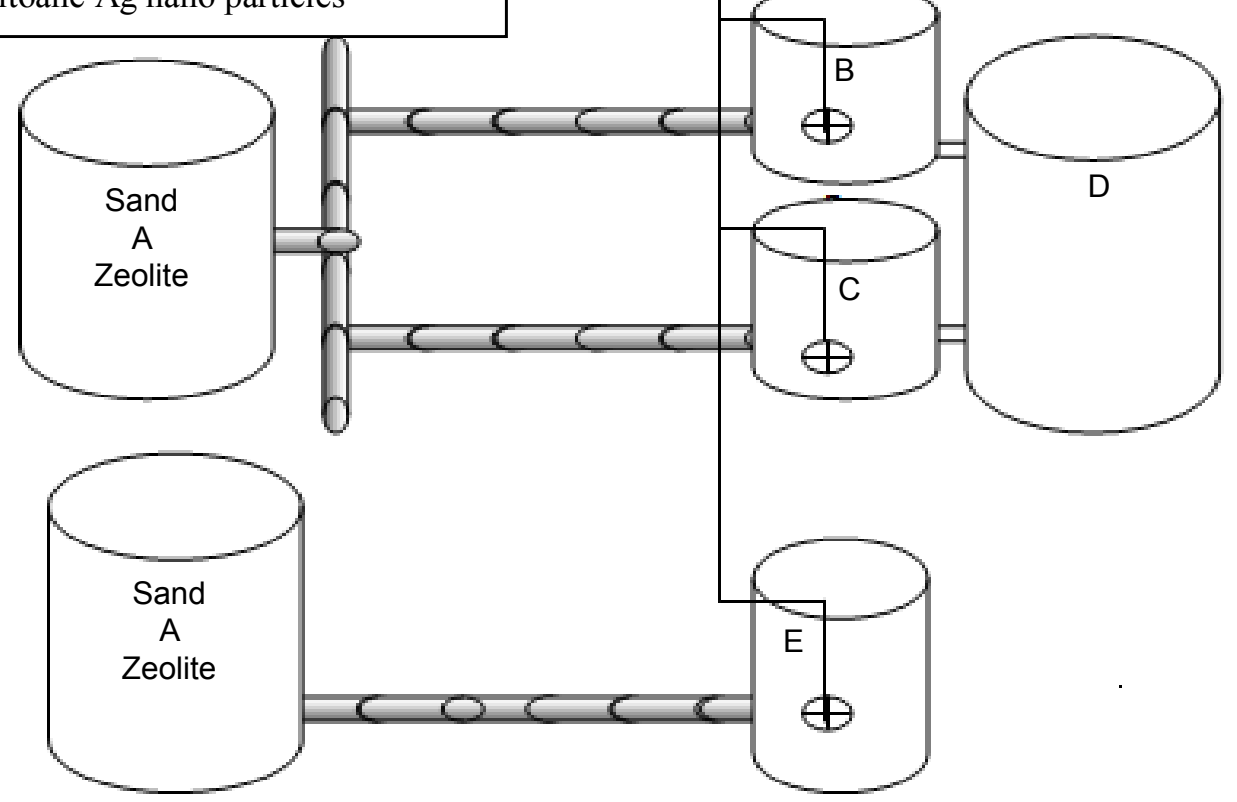

Figure 1: Schematic diagram of the compact treatment unit for dairy effluent biodegradation. 


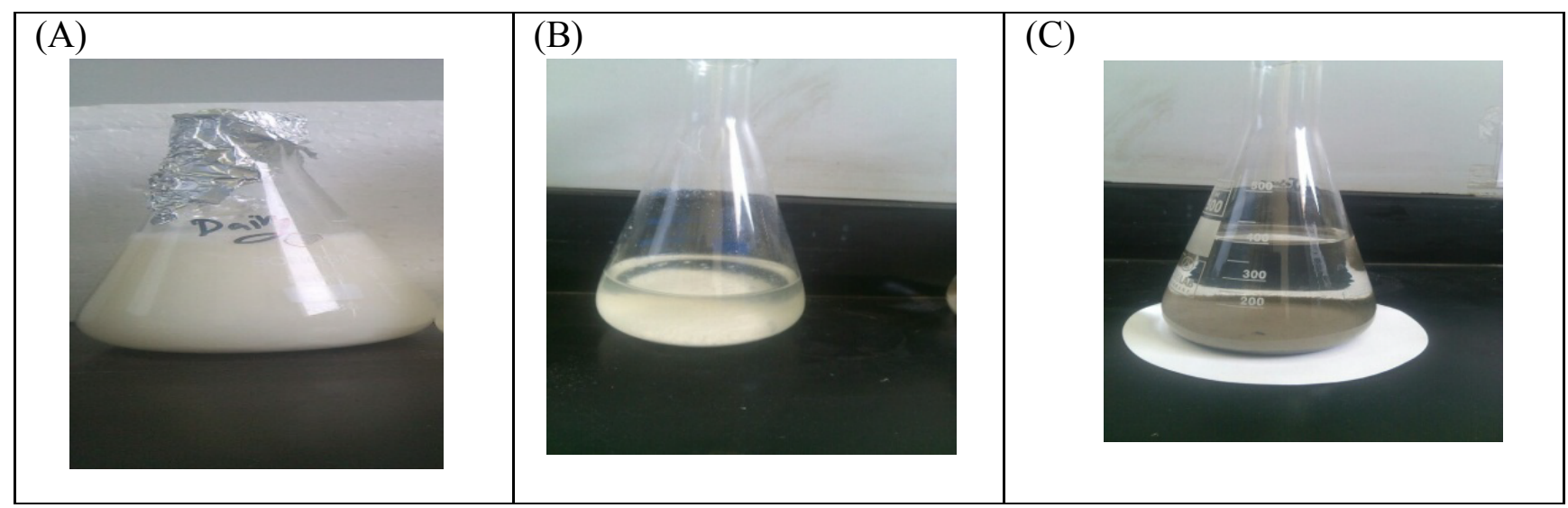

Figure 2: A) Influent dairy waste; B) Coagulation by chitosan; C) Chitosan-Ag nanoparticle.

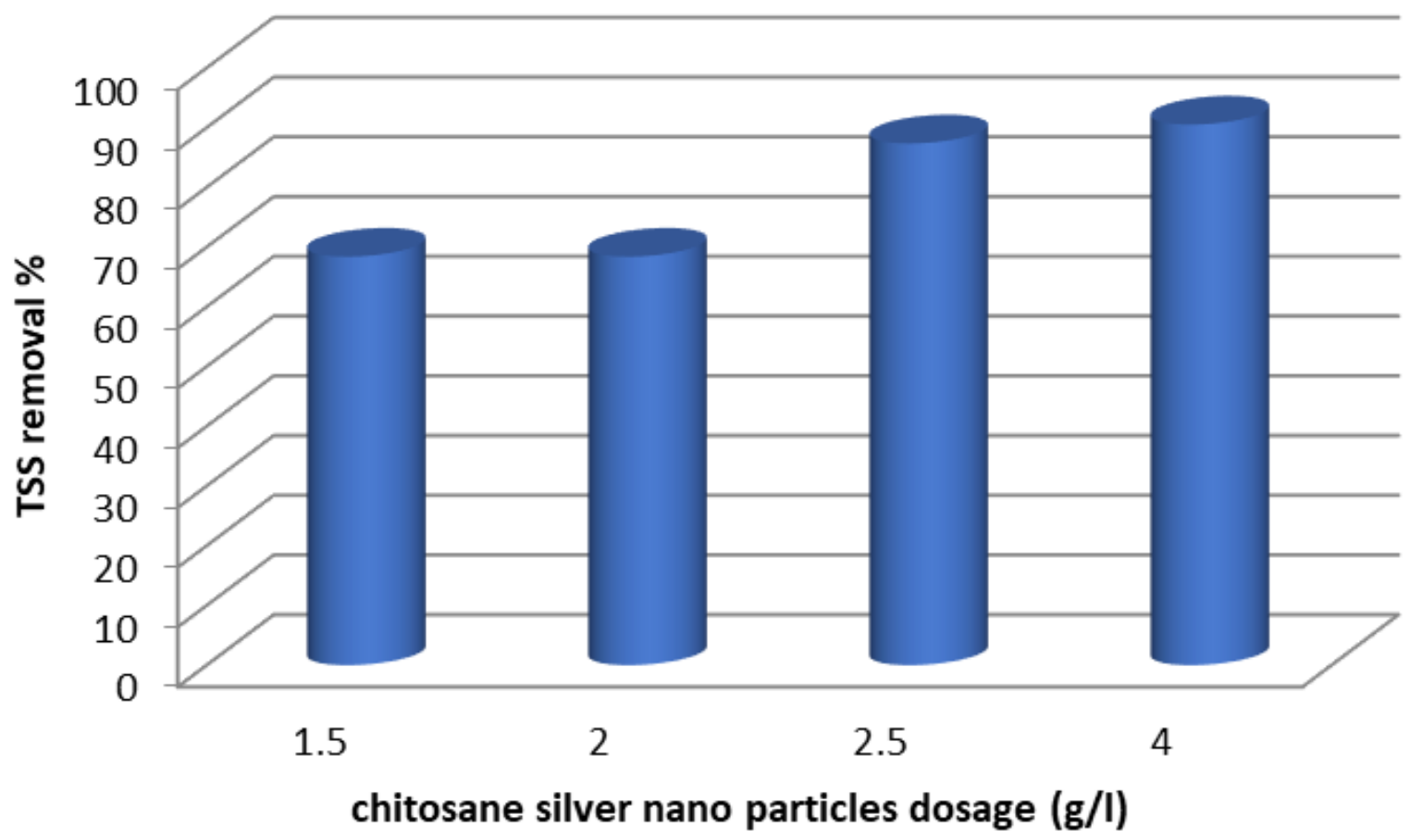

Figure 3: Chitosan Ag nanoparticle dosages on TSS removal.

fed with $2 \mathrm{~L}$ untreated dairy wastewater was given retention time of $2 \mathrm{~h}$, then the effluent flow to second tank was filled with immobilized of fungal isolate with alginate was added to the effluent was given a retention time at 7 days \& the third tank was fed with immobilized of bacterial isolate with alginate was added to the $2 \mathrm{~L}$ effluent was given a retention time at 7 days, then dairy effluent was allowed to flow into the coagulation tank was filled chitosan for 15 minutes after mixed was stopped and effluent was allowed to stand for $1 \mathrm{~h}$ allow settling. On the other hand, effluent of dairy flow into chitosan silver nanocomposites tank for 24 hour after aeration was stopped and effluent was allowed to stand for $1 \mathrm{~h}$ to allow settling. Constant aeration using a bubble diffuser was performed to obtain a concentration of $5 \mathrm{mgO}_{2} / \mathrm{L}$. Intermittent aeration consisted of air injections every $6 \mathrm{~h}$. Treated dairy effluent was tested physiochemically in the laboratory.

\section{Determination of the chitosan-Ag nanoparticle}

The one-step production of chitosan-Ag nanoparticle spheres is shown in Figure 3. Chitosan $(0.3 \mathrm{~g}$, dissolved in 10 $\mathrm{mL}$ of $2 \% \mathrm{v} / \mathrm{v} \mathrm{CH}_{3} \mathrm{COOH}$ solution) and $2 \% 50 \mathrm{~mL} \mathrm{AgNO}_{3}$ was mixed by constant stirring for 30 minutes, and then an $\mathrm{AgNO}_{3}-$ chitosan mixture solution was obtained. The $\mathrm{AgNO}_{3}$-chitosan mixture solution was then dropped into a $30 \%, 25 \mathrm{~mL} \mathrm{NaOH}$ solution. After 10 minutes, yellow-brown color spheres were yielded. Spheres were collected and washed twice with distilled deionized water to remove residual alkali [34].

\section{Characterization of chitosan-Ag nanoparticle}

After preparation of chitosan-Ag nanoparticle, the stock solution was measured by TEM (JEOL-JEM-2100), A UV-Vis spectrophotometer model: Thermo Scientific Orion AQ 8000 
Citation: Moustafa MT (2019) Comparative Study of Biodegradation and Coagulation of Dairy Effluent by Using Immobilized Microbial Isolates and Chitosane Silver Nano Particles and Production Biodiesel. Ann Microbiol Res 3(1):61-75

Table 1: The characteristics of studied of dairy wastewater before and after treatment.

\begin{tabular}{|c|c|c|c|c|c|c|c|}
\hline \multirow{2}{*}{ Parameter } & \multirow{2}{*}{$\begin{array}{l}\text { Dairy } \\
\text { effluent }\end{array}$} & \multirow{2}{*}{ Fungal stage } & \multirow{2}{*}{ Bacterial stage } & \multicolumn{4}{|c|}{ Concentration chitosan $3 \mathrm{~g} / 700 \mathrm{ml}$} \\
\hline & & & & 0.5 & 1 & 1.5 & 3 \\
\hline $\mathrm{pH}$ & 5.73 & 6.48 & 5.38 & 6.39 & 6.42 & 6.55 & 6.58 \\
\hline Colour & Milky White & Light green & Faint green & Semi clear & Semi clear & Semi clear & Semi clear \\
\hline $\operatorname{COD}(\mathrm{mg} / \mathrm{l})$ & $\begin{array}{l}3900 \pm \\
317.4\end{array}$ & $\begin{array}{l}1200 \pm 1.89 \times \\
102\end{array}$ & $\begin{array}{l}1500 \pm 2.54 \times \\
102\end{array}$ & $716 \pm 0.15 \times 102$ & $630 \pm 0.2 \times 102$ & $490 \pm 0.36 \times 102$ & $\begin{array}{l}423 \pm 0.251 \times \\
102\end{array}$ \\
\hline $\begin{array}{l}\text { Turbidity } \\
\text { (NTU) }\end{array}$ & $350 \pm 25.1$ & $120 \pm 0.15 \times 102$ & $97 \pm 0.107 \times 102$ & $76 \pm 0.035 \times 102$ & $66 \pm 0.035 \times 102$ & $45 \pm 0.035 \times 102$ & $27 \pm 0.025 \times 102$ \\
\hline $\mathrm{BOD}(\mathrm{mg} / \mathrm{l})$ & $1300 \pm 80.8$ & $136 \pm 0.32 \times 102$ & $200 \pm 0.36 \times 102$ & $89 \pm 0.015 \times 102$ & $76 \pm 0.047 \times 102$ & $57 \pm 0.025 \times 102$ & $44 \pm 0.04 \times 102$ \\
\hline TSS (mg/l) & $791 \pm 9.0$ & $400 \pm 1 \times 102$ & $490 \pm 0.95 \times 102$ & $195 \pm 0.05 \times 102$ & $\begin{array}{l}150 \pm 0.036 \times \\
102\end{array}$ & $\begin{array}{l}132 \pm 0.025 \times \\
102\end{array}$ & $109 \pm 0.01 \times 102$ \\
\hline $\mathrm{NH}_{4}(\mathrm{mg} / \mathrm{l})$ & $37 \pm 2.08$ & - & - & $\begin{array}{l}13.8 \pm 0.076 \times \\
102\end{array}$ & $11 \pm 0.01 \times 102$ & $8.6 \pm 0.76 \times 102$ & $2.7 \pm 0.25 \times 102$ \\
\hline
\end{tabular}

Aqua Mate 8000 was used to record silver plasmon band and Fourier transform infrared spectroscopy (FT-IR-jasco 4600).

\section{Bio-oil extraction}

Preparation of fungal cultures: Oleaginous fungus $M$. circinelloides was grown in the medium with the following components (in gL-1): Glucose, 20.0; $\left(\mathrm{NH}_{4}\right)_{2} \mathrm{SO}_{2}, 1.4 ; \mathrm{KH}_{2} \mathrm{PO}_{4^{\prime}}$ 2.0; $\mathrm{MgSO}_{4} .7 \mathrm{H}_{2} \mathrm{O}, 0.3 ; 0.7 \mathrm{~K}_{2} \mathrm{HPO}_{4} ; 0.6$ yeast extract and sterilized by autoclaving. The broth was inoculated with the isolated fungal strains and incubated at $28^{\circ} \mathrm{C}$ in rotary shaker at $120 \mathrm{rpm}$ for 5 days. The fungal biomass determination $M$. circinelloides $\mathrm{gl}^{-1}$. The fungal biomass of screened isolates, mycelia were harvested from the incubated flasks by suction filtration through Whatman No 1 filter paper and thoroughly washed with distilled water. Then filtered mycelia dried at $65{ }^{\circ} \mathrm{C}$ in an oven for $2 \mathrm{hrs}$. The weight of the dried sample was calculated and dry biomass was expressed in $\mathrm{gl}^{-1}$. In the above mentioned media the carbon source was replaced by various low cost substrates such as molasses, Banana peel, sugarcane and water hyacinth to test the ability of oleaginous fungi to accumulate lipids when grown on agro-industrial wastes. These low cost carbon substrates were sun dried and grounded into fine powder. The fine powdered carbon source raw materials were then sieved with $0.2 \mathrm{~mm}$ in diameter sieve and kept in desiccators until required for use. We have used concentration of dilute $\mathrm{H}_{2} \mathrm{SO}_{4}(5 \% \mathrm{wt} / \mathrm{wt})$ for retention time $120 \mathrm{~min}$ at temperature $\left(120^{\circ} \mathrm{C}\right)$ for pretreatment of raw material. The fungal was inoculated in the production medium and kept in shaker at $150 \mathrm{rpm}$.

Extraction of lipid compounds: Lipids were extracted following modified the method of Bligh and Dyer [35]. The obtained biomass (dry weight) was transferred to 50 $\mathrm{ml}$ centrifugal tube and $20 \mathrm{ml}$ of $\mathrm{HCl}(4 \mathrm{M})$ was added and incubated at $60{ }^{\circ} \mathrm{C}$ for $1 \mathrm{~h}$, then kept at- $80{ }^{\circ} \mathrm{C}$ for 2 hours and subsequently in boiling water for $10 \mathrm{~min}$. This freezing process was repeated 2 times in order to break up the cells. The extraction was performed with $1.0 \mathrm{~g}$ dried biomass in a glass vessel containing $30 \mathrm{ml}$ methanol and toluene [36]. The extraction was assisted by avortex in $10 \mathrm{~min}$. After vortexing, further extraction with $30 \mathrm{ml}$ chloroform/methanol (1:1) were added into the tube, shacked vigorously with a vortex and then centrifuged at $3000 \mathrm{rpm}$ for $10 \mathrm{~min}$. The lipid containing chloroform layer (the lower layer) lower chloroform layer was filtered on filter paper containing $1.0 \mathrm{~g}$ of anhydrous sodium sulfate and collected in vials pre-weighed glass. This procedure was repeated for the extraction of lipids remaining in the sample. All the organic phases were pooled and the solvent removed in atmosphere of nitrogen. Lipids content was expressed as gram lipid per liter.

Determination of fatty acids profile by GC with FID: A known amount $(50 \mu \mathrm{l})$ of each extracted lipid was added into a glass tube and reacted with $0.6 \mathrm{ml}$ of $\mathrm{KOH}(0.5 \mathrm{~N})$ in methanol at $80^{\circ} \mathrm{C}$ for $10 \mathrm{~min}$, then $1 \mathrm{ml}$ of Boron trifluoride methanol complex was added to each tube and incubated at $80^{\circ} \mathrm{C}$ for $10 \mathrm{~min}$. Two milliliters of distilled water was added to stop the reaction, the suspension was vortexed vigorously. Equal volume of hexane was added to each tube and mixed thoroughly. After $30 \mathrm{~min}$ the upper phase containing the fatty acids methyl esters (FAMEs) were taken out and then transferred into a new clean tube for gas chromatography (GC) analysis. The gas chromatography (7890A, Agilent Technologies, USA) was equipped with aflame ionization detector (FID) and a capillary column DB225 (30 m × $0.25 \mathrm{~m}$ $\times 0.25 \mu \mathrm{m}$ film thickness). The injector temperature was 250 ${ }^{\circ} \mathrm{C}$; the initial column temperature was $160^{\circ} \mathrm{C}$ and rose to the final temperature of $250{ }^{\circ} \mathrm{C}$ at a rate of $3^{\circ} \mathrm{C}$ per min; and the detector temperature was $250^{\circ} \mathrm{C}$. The carrier gas was helium at a flow rate of $450 \mathrm{~mL} / \mathrm{min}$.

\section{Statistical analysis}

One way-ANOVA was performed to calculate significant differences in treatment means. SPSS version 20.0 software was used for interpretation of data. Data with a pvalue $<0.05$ were considered significantly different. All experiments were done in triplicate.

\section{Results and Discussion}

\section{Characterization of dairy effluent}

In the present investigation, Table 1 summarizes the obtained various of the physicochemical analysis for untreated dairy wastewater. 
Citation: Moustafa MT (2019) Comparative Study of Biodegradation and Coagulation of Dairy Effluent by Using Immobilized Microbial Isolates and Chitosane Silver Nano Particles and Production Biodiesel. Ann Microbiol Res 3(1):61-75

pH: The influent dairy wastewater was slightly acidic (5.86) The acidic $\mathrm{pH}$ is attributed to the breakdown of milk lactose into lactic acid [37]. It was variable even after treatment by using bacterial isolate $\mathrm{pH} 5.38$, while in fungi unite $\mathrm{pH}$ observed to be slightly acidic 6.48 .

Total suspended solids (TSS): The concentration of suspended solids in dairy effluent $791 \mathrm{mg} / \mathrm{L}$. The percent reduction in total suspended solids of treated dairy effluent is recorded in (Figure 3). It is depicted in the (Table 1) that after treatment by fungi and Lactobacillus units for 7 days the percent reductions shown by fungal was $49.2 \%$. Reduction efficiency of bacteria Lactobacillus was $46.3 \%$. It is clear that fungal caused the highest reduction where as bacterial caused least reduction in TSS. The efficiency of chitosan in the removal of TSS for dairy wastewater is shown in Figure 1. It can be observed that the performance of the chitosan is influenced by the $\mathrm{pH}$ of the effluent. The optimum $\mathrm{pH}$ value of the dairy wastewater was found to be in the $\mathrm{pH}$ 6.58. An interaction between $\mathrm{NH}_{3}^{+} p$ functional groups and anionic mineral particles which attract colloidal particles in the medium which get neutralized and settle down as flocs. On the other hand, in Figure 4 shows, the results indicates the effects of varying the dosages of chitosan-Ag nanoparticle, the clarity of water increase with increase concentration doses from $68.3 \%$ at 1 $\mathrm{g} / \mathrm{l}$, to $90 \%$ at $4 \mathrm{~g} / \mathrm{l}$. The reduction in TSS after aeration might be due to use of suspended organics by microorganisms for their growth and development. The overall reduction after filtration is directly associated with the uses of fungus, bacteria and chitosan-Ag nanoparticle.

Turbidity: Turbidity is a critical parameter for public water supplies and disinfection processes. The efficiency of turbidity removal is an important parameter to check the efficiency of coagulation. It can be seen that turbidity removal efficiency was $72.2 \%$ for $M$. circinelloides and $65.7 \%$ for Lactobacillus at 7 days, it can be seen that fungi caused highest reduction in turbidity than bacteria. Turbidity decreased due to consumption of organic materials and suspended particles by $M$. circinelloides/Lactobacillus through growth and survival. Under the condition controlling solution $\mathrm{pH}$ (6.58), the residual turbidities after mixing with various dosages of chitosan ( 0.3 to $2 \mathrm{~g} / 700 \mathrm{ml}$ ) of dairy wastewater were shows in (Table 1). It says that the residual turbidity reduced as the coagulation dosage increased. Indeed, in this, it is shown that the percentage removal of turbidity of dairy wastewater was enhanced by increasing the chitosan concentration up to 3 $\mathrm{g} / \mathrm{l}$. It's clear that effective coagulation was achieved with much lower doses of chitosan than would be required for complete charge neutralization of particles, and this process was guided by the combined effects of electrostatic patch and bridging mechanisms. This coagulation process was fast; turbidity removal was achieved within $30 \mathrm{~min}$ at natural $\mathrm{pH}$. This is because the chitosan is a bio multi polymer, has a positive charge and contains free amine groups which give high capability for chemical relevance with molecules that have negative charges such as proteins, fats and mineral ions [38]. As can be observed from Figure 4, the turbidity was decreased with increasing chitosan-Ag nanoparticle concentration. When chitosan-Ag nanoparticle concentration increased to $4 \mathrm{~g} / \mathrm{l}$ increases the water clarity up to $93.75 \%$. The turbidity had decreased from 350 to 20 NTU for $24 \mathrm{~h}$.

Biochemical oxygen demand (BOD): Biochemical oxygen demand is widely used as an indication of water quality. It can be seen that after reduction by fungal and bacterial units as seen in (Table 1), the reductions in BOD values for bacteria

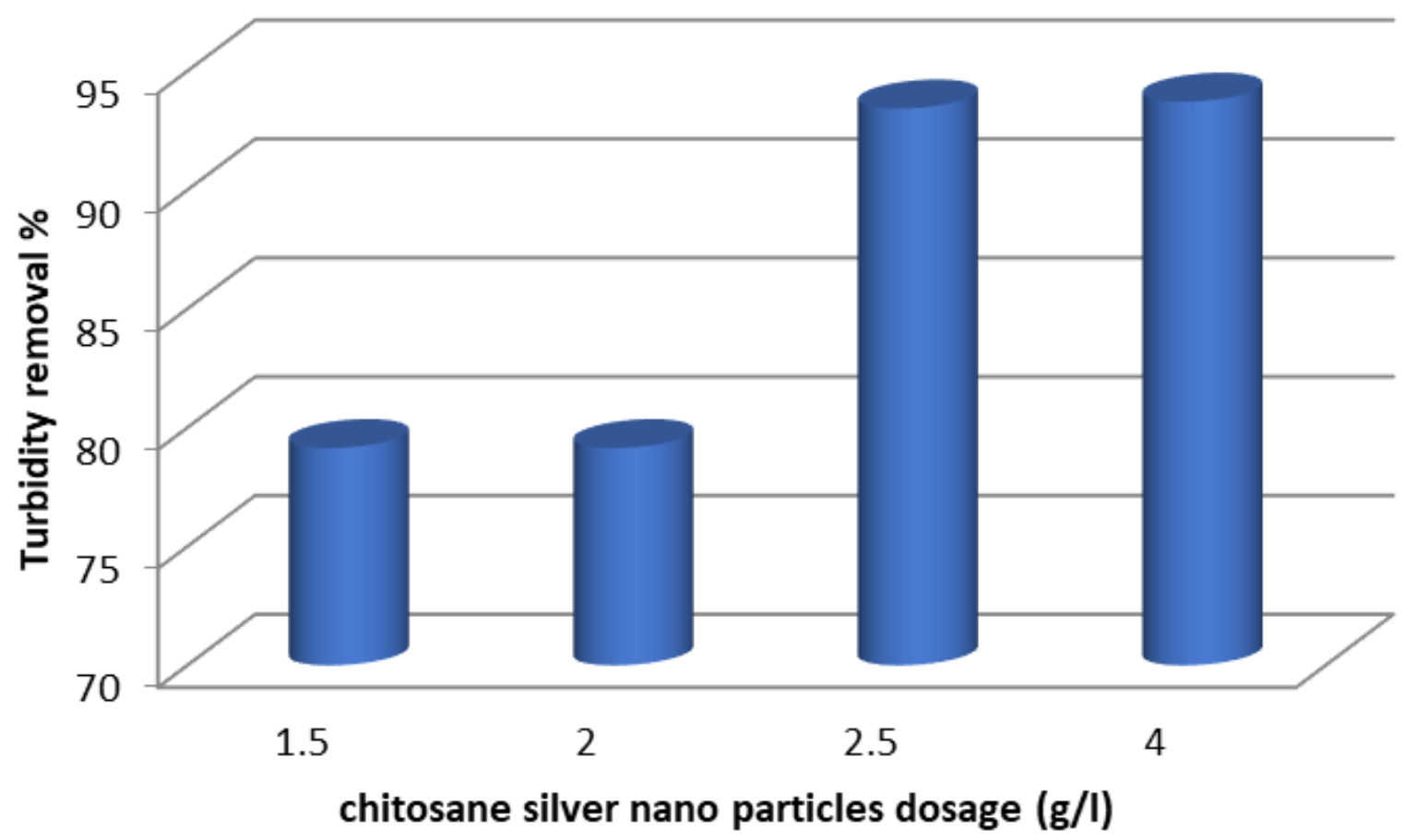

Figure 4: Effect of chitosan-Ag nanoparticle dosage on Turbidity removal. 
Citation: Moustafa MT (2019) Comparative Study of Biodegradation and Coagulation of Dairy Effluent by Using Immobilized Microbial Isolates and Chitosane Silver Nano Particles and Production Biodiesel. Ann Microbiol Res 3(1):61-75

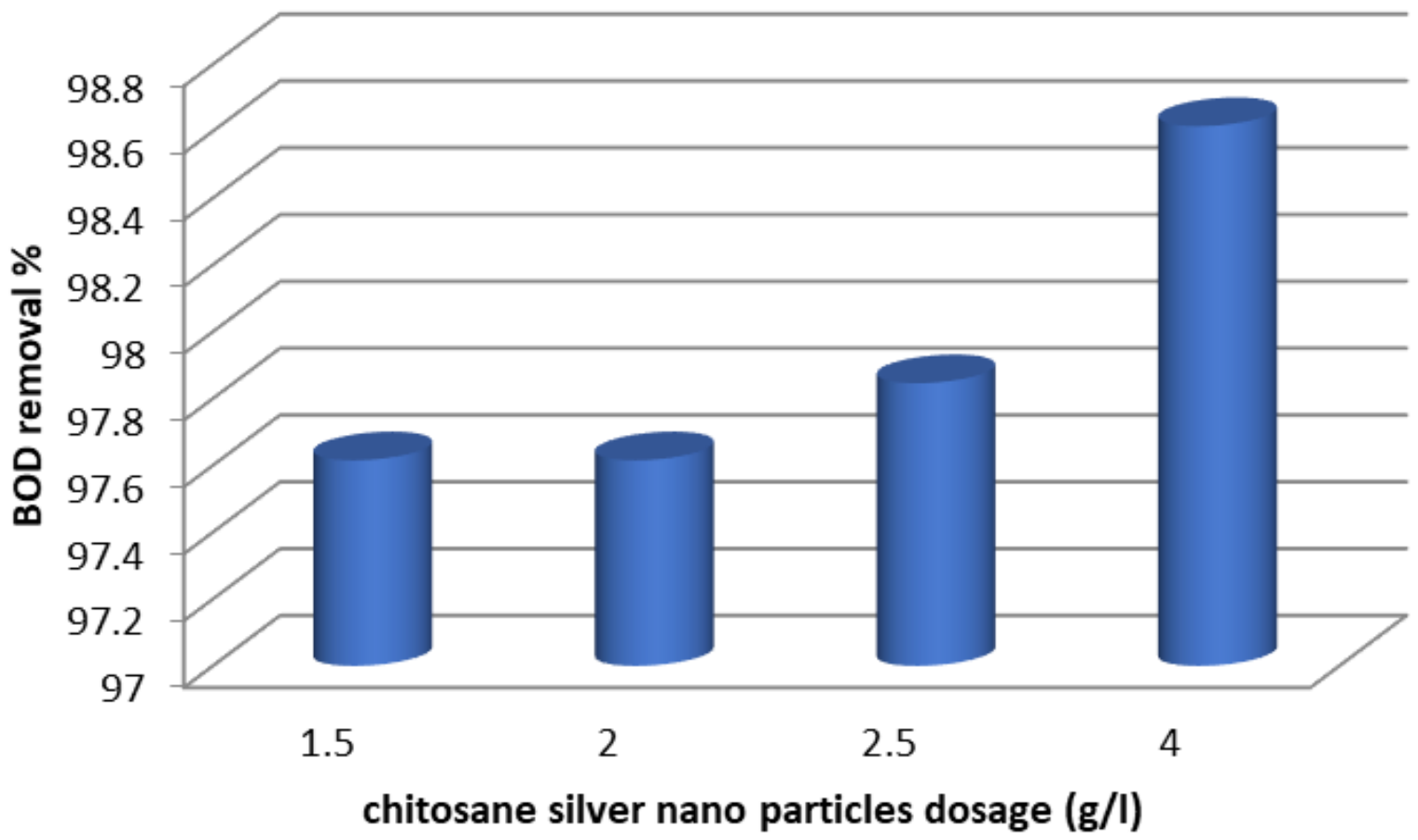

Figure 5: Effect of chitosan-Ag nanoparticle dosages on BOD removal.

Lactobacillus was $84.6 \%$, but the reduction efficiency of $M$. circinelloides was highest with $88.4 \%$ of BOD. The significant decrease in BOD values could be associated with consumption of organic material by microbes as a food source. The results of analysis of water treated with 1 to $4 \mathrm{~g} / \mathrm{l}$ chitosanAg nanoparticle shown in Figure 5, shows that yields have become clarification of organic materials for optimum dose of $4 \mathrm{~g} / \mathrm{l}$ of chitosan-Ag nanoparticle $98.6 \%$ for BOD at $24 \mathrm{~h}$.

Chemical oxygen demand (COD): The graphical representation (Table 1 ) show the COD values that are observed during at 7 days treatment of the effluent after reduction by fungal and bacterial units were significantly reduced by fungal and Lactobacillus $74.3 \%$ and $69.2 \%$ respectively. From the graphs it is very clear that the COD of the effluent is continuously decreasing and it indicates that the strains used for treating the effluent are helpful in COD reduction. The best reduction efficiency of the effluent, whereas; fungal showed highest reduction in COD. The surface charge of the chitosan effectively varies with varying the $\mathrm{pH}$ of the wastewater. So, the experiments were performed at $\mathrm{pH}$ 6.58. chitosan dosage of 0.3 to $3 \mathrm{~g} / 700 \mathrm{ml}$, settling time of $1 \mathrm{~h}$ as constant and the observation is depicted in Table 1. From the Table 1, it was observed that the percentage of COD removal increased with increasing initial $\mathrm{pH}$ up to 6.58 . This is mainly due to the formation $-\mathrm{NH}_{3}{ }^{+}$ions in acidic conditions, which could adsorbs the negatively charged organic matters present in the wastewater significantly [39] and increased the removal efficiency of $\operatorname{COD}(88.4 \%)$ up to the $\mathrm{pH}$ of 6.58 . It can be seen from Figure 6 that COD concentration was decreased with increase of chitosan-Ag nanoparticle concentration $(\mathrm{g} / \mathrm{l})$. When chitosan- $\mathrm{Ag}$ nanoparticle concentration was 1 to $4 \mathrm{~g} / \mathrm{l}$, the COD reached $76.9 \%$ to $90 \%$ at $24 \mathrm{~h}$. Our results are in accordance with the reduction in COD seen by [40] had also reported $67.1 \%$ and $48.3 \%$ reduction in COD of diary wastewater with use of two bacterial strains namely Neisseria $s p$. and Citrobacter $s p$.

Removal of ammonia: At elevated concentrations, ammonia can be an environmental problem due to its toxicity, especially to aquatic organisms [41]. It was observed that the concentration ammonia was decreased after filtration by zeolite to $12 \mathrm{mg} / \mathrm{l}$ with removal efficiency (45.9\%) and after treatment by chitosan-Ag nanoparticle, it was observed the resulted in greater efficiency of removal of ammonia from the effluent (Figure 7), due to the increased surface area of the adsorbent and the availability of more adsorption sites. The use of $(4 \mathrm{~g} / \mathrm{l})$ chitosan-Ag nanoparticle removed $97.1 \%$ of the ammonia from the effluent after $2 \mathrm{~h}$ of recirculation, with 0.07 $\mathrm{mg} \mathrm{L}^{-1}$ of ammonia remaining in the effluent.

\section{Effects of Chitosane AgNP on Bacteria of Dairy Wastewater}

As given in (Table 2), illustrated that the results for the total colifrom in influent was recorded (70000 CFU/100 ml) and after 40 and 60 minutes were recorded 3800 and 200 CFU/100 $\mathrm{ml}$ with removal $94.5 \%$ and $97.5 \%$ respectively, while at $2 \mathrm{~h}$ the concentration bacteria was reduced to nil. As the results indicate, removal percentage is significantly increased by the increase of time.

The results are presented in (Table 2). Revealed that the results for the fecal colifrom in influent was recorded $(20000$ CFU/100 ml) and after 40 and 60 minutes were recorded 1700 and $60 \mathrm{CFU} / 100 \mathrm{ml}$ with removal $94.5 \%$ and $97.5 \%$ respectively, while at $2 \mathrm{~h}$ the concentration bacteria was reduced to nil. As the results indicate, removal percentage is 
Citation: Moustafa MT (2019) Comparative Study of Biodegradation and Coagulation of Dairy Effluent by Using Immobilized Microbial Isolates and Chitosane Silver Nano Particles and Production Biodiesel. Ann Microbiol Res 3(1):61-75

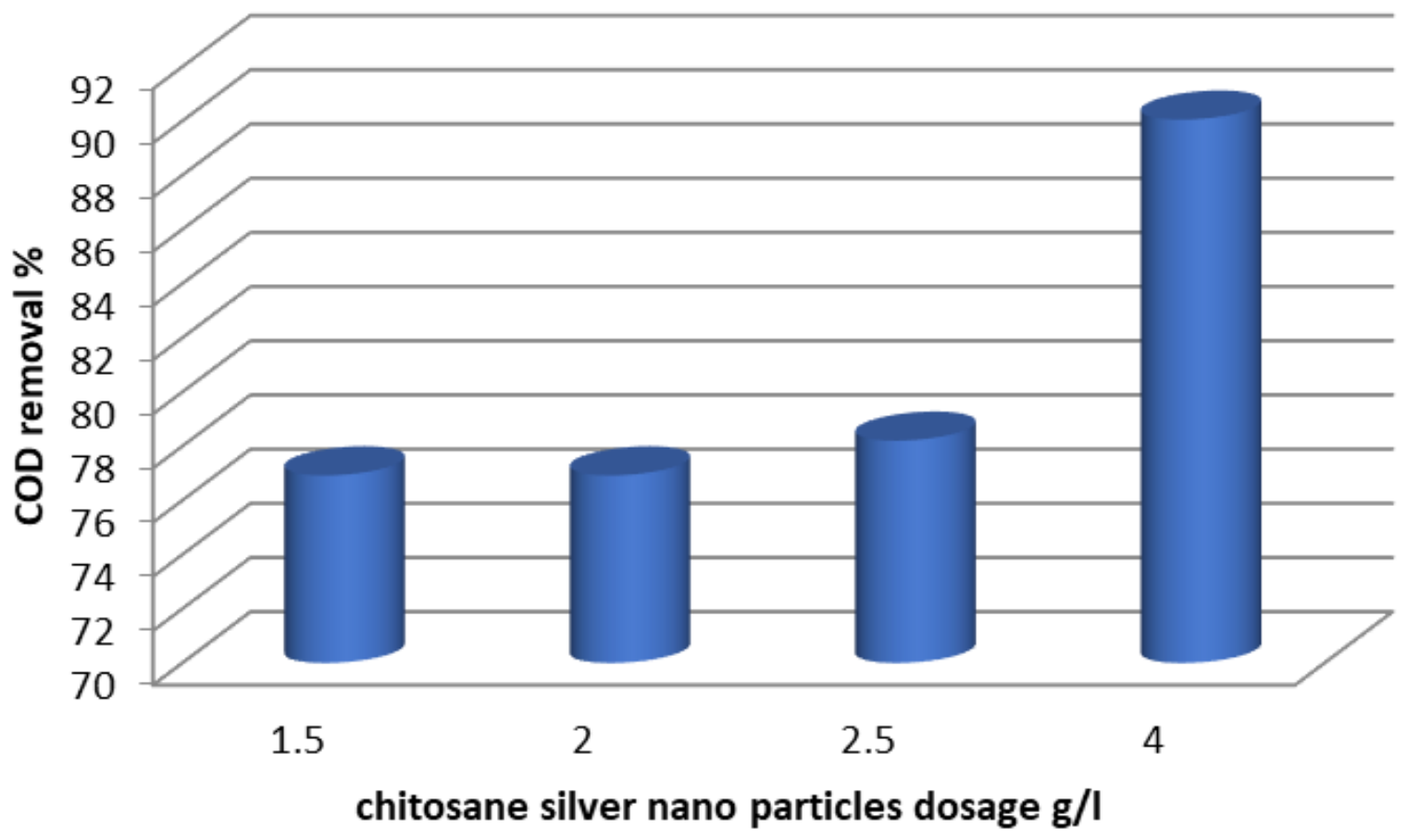

Figure 6: Effect of chitosan-Ag nanoparticle dosages on COD removal.

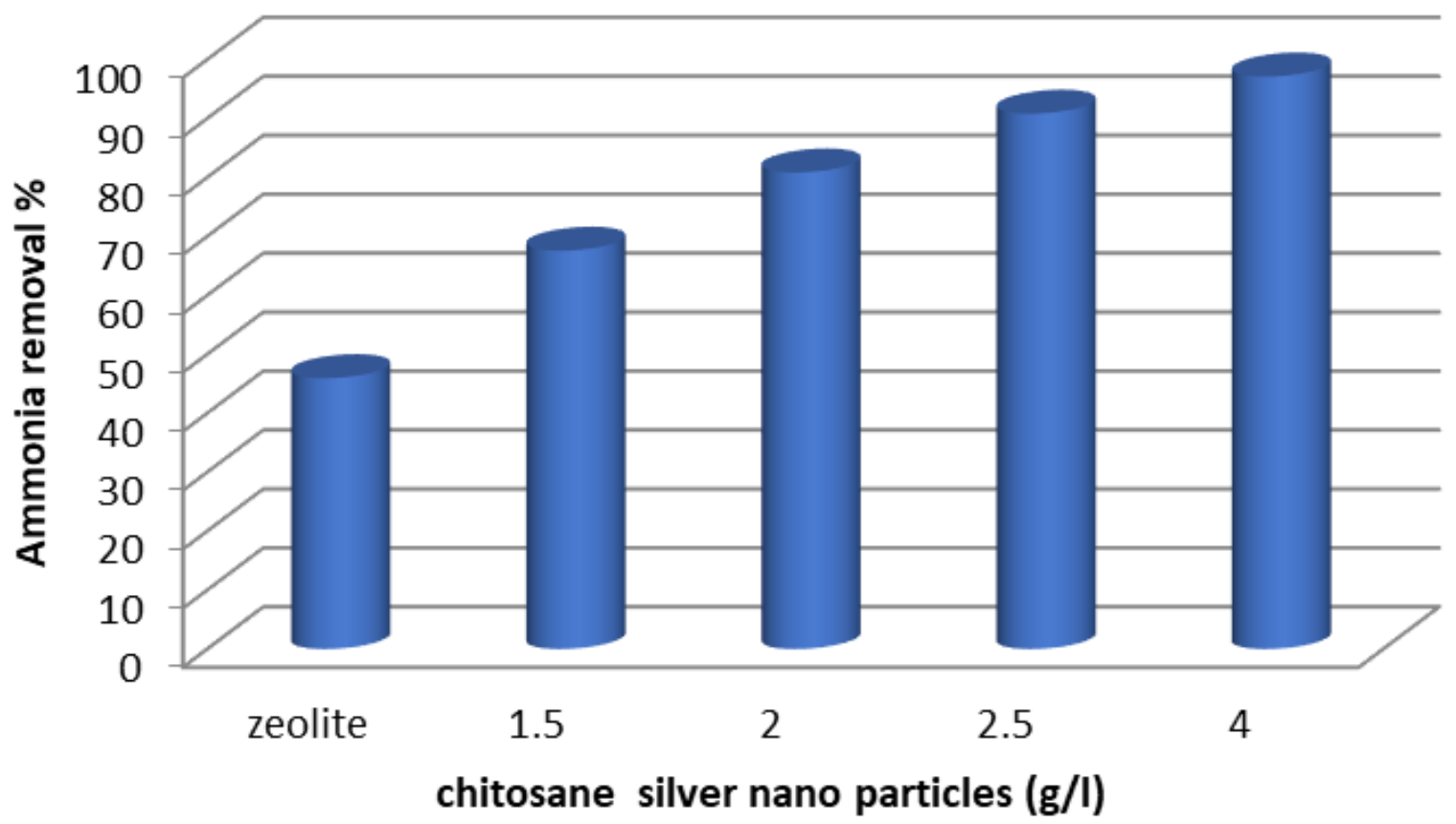

Figure 7: Effect of zeolite and concentration chitosan-Ag nanoparticle on ammonia removal.

significantly increased by the increase of time.

Given the analytical results in (Table 2), it could be noticed that, the fecal streptococci counts were relatively high at influent with (1800 CFU/100 ml). These counts were remarkably decreased in effluent water after 40 minute was recorded $500 \mathrm{CFU} / 100 \mathrm{ml}$ with removal $72 \%$ while at $1 \mathrm{~h}$ was rescored $5 \mathrm{CFU} / 100 \mathrm{ml}$ with removal $99.0 \%$, while at $2 \mathrm{~h}$ the concentration bacteria was reduced to nil.

It can be seen from (Table 2), illustrated that the results for the pseudomonas aeruginosa in influent was recorded (20000 CFU/100 ml) and after 40, 60 and 120 minutes were recorded $4000,2800,2500 \mathrm{CFU} / 100 \mathrm{ml}$ with removal $80 \%$, 
Citation: Moustafa MT (2019) Comparative Study of Biodegradation and Coagulation of Dairy Effluent by Using Immobilized Microbial Isolates and Chitosane Silver Nano Particles and Production Biodiesel. Ann Microbiol Res 3(1):61-75

Table 2: Effect of different contact times of chitosan-Ag nanoparticle on microbial contamination.

\begin{tabular}{|c|c|c|c|c|c|}
\hline \multirow[t]{2}{*}{ Bacterial tests (CFU/100 ml) } & \multirow[b]{2}{*}{ Influent } & \multicolumn{4}{|c|}{ chitosan-Ag nanoparticle $(4 \mathrm{~g} / 700 \mathrm{ml})$} \\
\hline & & 40 minute & 1 hour & 2 hours & 4 hours \\
\hline $\begin{array}{l}\text { Total coliform CFU/100 ml) } \\
\text { (mean } \pm \text { S.D/100 ml) }\end{array}$ & $100000 \pm 15 \times 10^{3}$ & $3500 \pm 4 \times 10^{2}$ & $600 \pm 0.5 \times 10^{2}$ & 0 & 0 \\
\hline $\begin{array}{l}\text { Fecal colifrom (CFU/100 ml) } \\
(\text { mean } \pm \text { S.D } / 100 \mathrm{ml})\end{array}$ & $20000 \pm 2 \times 10^{2}$ & $1700 \pm 2.5 \times 10^{2}$ & $60 \pm 7.6$ & 0 & 0 \\
\hline $\begin{array}{l}\text { Fecal streptococci CFU/100 ml) } \\
(\text { mean } \pm \text { S.D } / 100 \mathrm{ml})\end{array}$ & $1850 \pm 1.3 \times 10^{2}$ & $500 \pm 1 \times 10^{2}$ & $7 \pm 2.5$ & 0 & 0 \\
\hline $\begin{array}{l}\text { pseudomonas aeruginosa } \mathrm{CFU} / 100 \mathrm{ml} \text { ) } \\
\text { (mean } \pm \mathrm{S} . \mathrm{D} / 100 \mathrm{ml} \text { ) }\end{array}$ & $200000 \pm 104 \times 10^{3}$ & $4000 \pm 2.5 \times 10^{2}$ & $2800 \pm 2 \times 10^{2}$ & $330 \pm 3.6$ & 0 \\
\hline
\end{tabular}

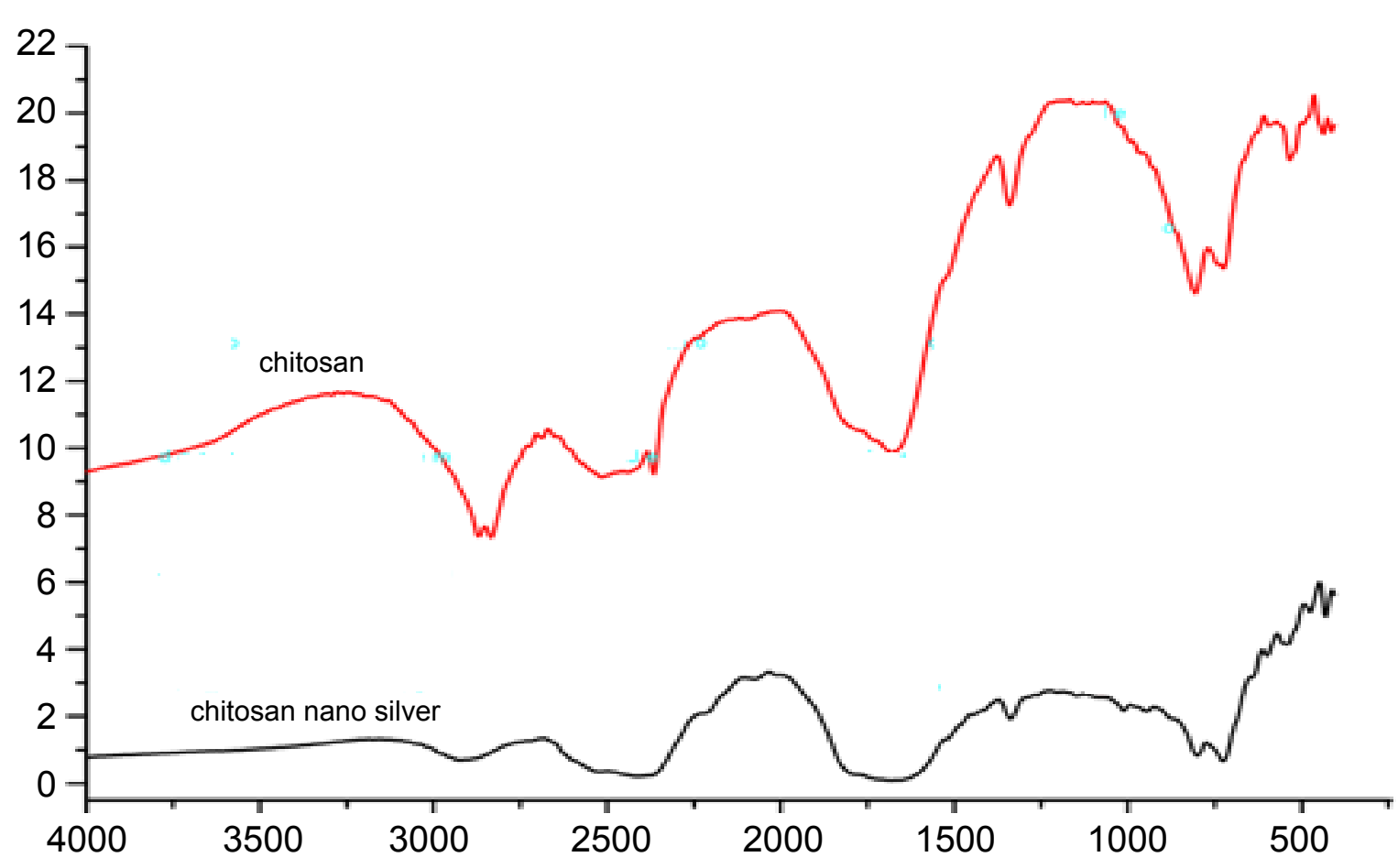

Figure 8: FTIR spectrum of chitosan silver nanoparticles.

$86 \%$ and $87.5 \%$ respectively, while at $4 \mathrm{~h}$ the concentration bacteria was reduced to nil. As the results indicate, removal percentage is significantly increased by the increase of time.

Removal percentage of total coliform, fecal coliform, fecal streptococci and pseudomonas aeruginosa have a significant difference with four other times $(p<0.05)$. Comparing the removal percentage in 40,60 and 120 minutes there is no significant difference $(p<0.05)$.

Nano silver chitosan molecule has the ability to interact with bacterial surface and is adsorbed on the surface of the cells and stacks on the microbial cell surface and for mingan impervious layer around the cell, leading to the block of the channels [42]. The chitosan inhibits the bacteria during electrostatic reactions between anime group $\left(\mathrm{NH}^{+}\right)$of chitosan and phosphoryl groups of phospholipids, which are found in the cell walls of bacteria [43]. Generally, cell walls of G-bacteria contain a highest fat ratio than cell walls of G+ bacteria.
The possible mechanisms are as follows, the electrostatic interaction between positive charged silver metal ions with the negative charged DNA and protein molecules could collapse the structure and function of DNA and protein [44]. Kim, et al. 2007 [45] suggested that the free radicals might be involved in the membrane damage. They have depicted that the antioxidant ( $\mathrm{N}$-acetyl cysteine) could influence the antibacterial activity of free radicals which may be released from the surface of silver nanoparticles.

\section{Silver Chitosan Nanocomposites Analysis by FT-IR Spectrophotometry}

Figure 8 Shows the FTIR spectra of the chitosan-Ag nanoparticle spheres. The bands between $3,500 \mathrm{~cm}^{-1}$ and $3294 \mathrm{~cm}^{-1}$ due to overlapping of $\mathrm{O}-\mathrm{H}$ and amine N-H stretching bands. The bands between $2,925 \mathrm{~cm}^{-1}$ corresponded to the alkane $\mathrm{C}-\mathrm{H}$-stretching lipids. The bands between 1,659 and $1586 \mathrm{~cm}^{-1}$ corresponded to the amino groups of amide. 1715 ( $C=0$ stretching). The bands between 1450, 1376, and 
Citation: Moustafa MT (2019) Comparative Study of Biodegradation and Coagulation of Dairy Effluent by Using Immobilized Microbial Isolates and Chitosane Silver Nano Particles and Production Biodiesel. Ann Microbiol Res 3(1):61-75

$1318 \mathrm{~cm}^{-1}$ for $\mathrm{C}-\mathrm{H}$ bending. Of $1000-1157 \mathrm{~cm}^{-1}$ (CO stretching) were common in spectra due to the chitosan backbone. The peaks observed at $845,751,665$ and $604 \mathrm{~cm}^{-1}$ correspond to $\mathrm{C}-\mathrm{H}$ stretching of alkenes. The FTIR spectrum of chitosan shows $\mathrm{O}-\mathrm{H}$ stretching at $3,243 \mathrm{~cm}^{-1}, \mathrm{C}-\mathrm{H}$ and $\mathrm{C}-\mathrm{N}$ stretching at $2,925 \mathrm{~cm}^{-1}, \mathrm{~N}-\mathrm{H}$ bending at $1,637 \mathrm{~cm}^{-1}, \mathrm{~N}-\mathrm{H}$ angular deformation in $\mathrm{CO} \mathrm{NH}$ plane at $1,544 \mathrm{~cm}^{-1}$ and $\mathrm{C}-\mathrm{O}-\mathrm{C}$ band stretching at $1,141 \mathrm{~cm}^{-1}$.

\section{TEM Analysis}

The natural polymer chitosan nucleates, as well as stabilizes the silver nanoparticles formed and, thus, prevents aggregation of silver nanoparticles. The reason is the excellent chelating property of chitosan backbone, which binds the silver to it. Here it is reduced by $\mathrm{NaOH}$ and stabilized by the chitosan chains [15]. TEM micrographs shown in Figure 9 clearly depict the uniformly distributed silver nanoparticles embedded in chitosan. All particles exhibits poly dispersed and semi spherical morphology, the silver nanoparticles are visible as dark spots inside the chitosan-Ag nanoparticle with size approximately between 8 and $30 \mathrm{~nm}$.

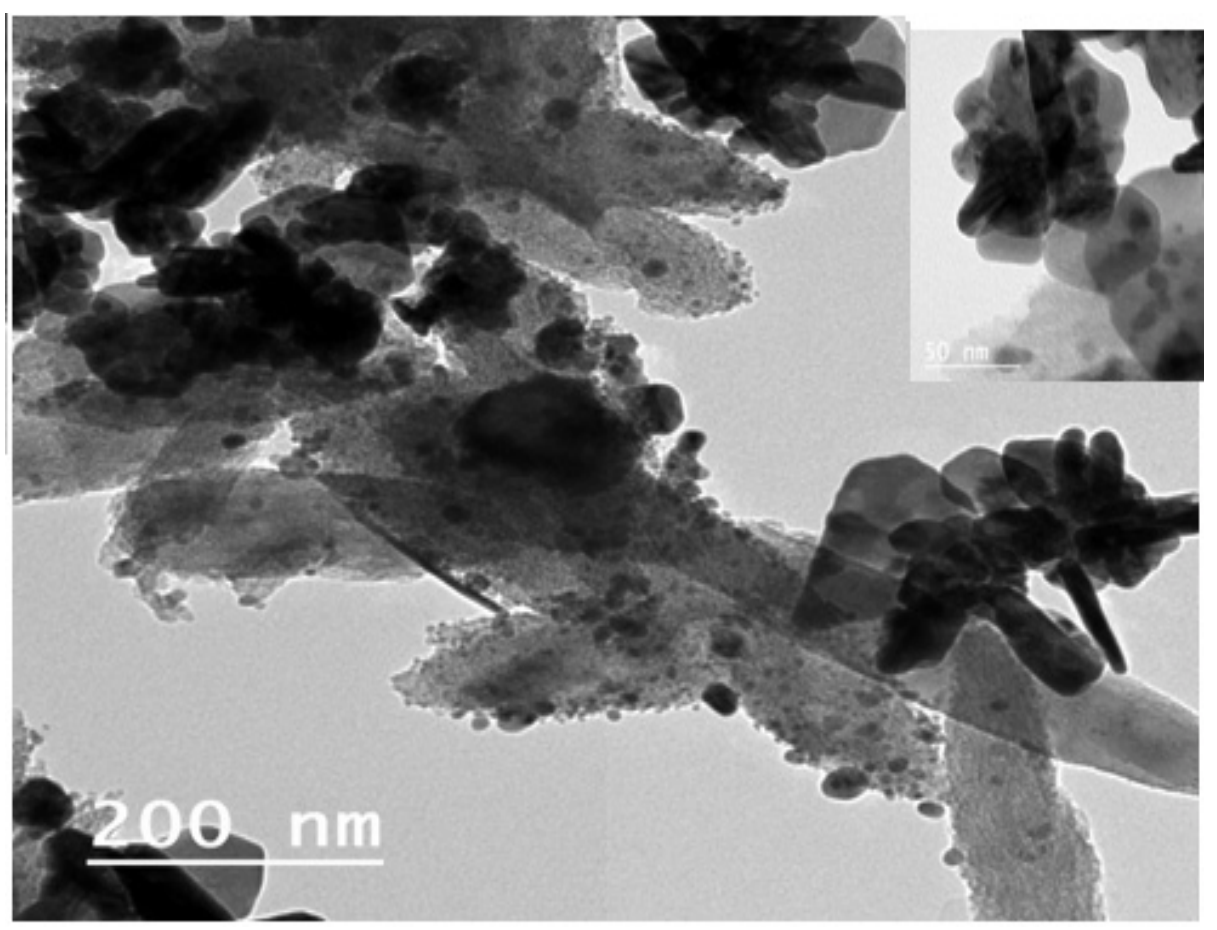

Figure 9: TEM image of the chitosan-Ag nanoparticle.

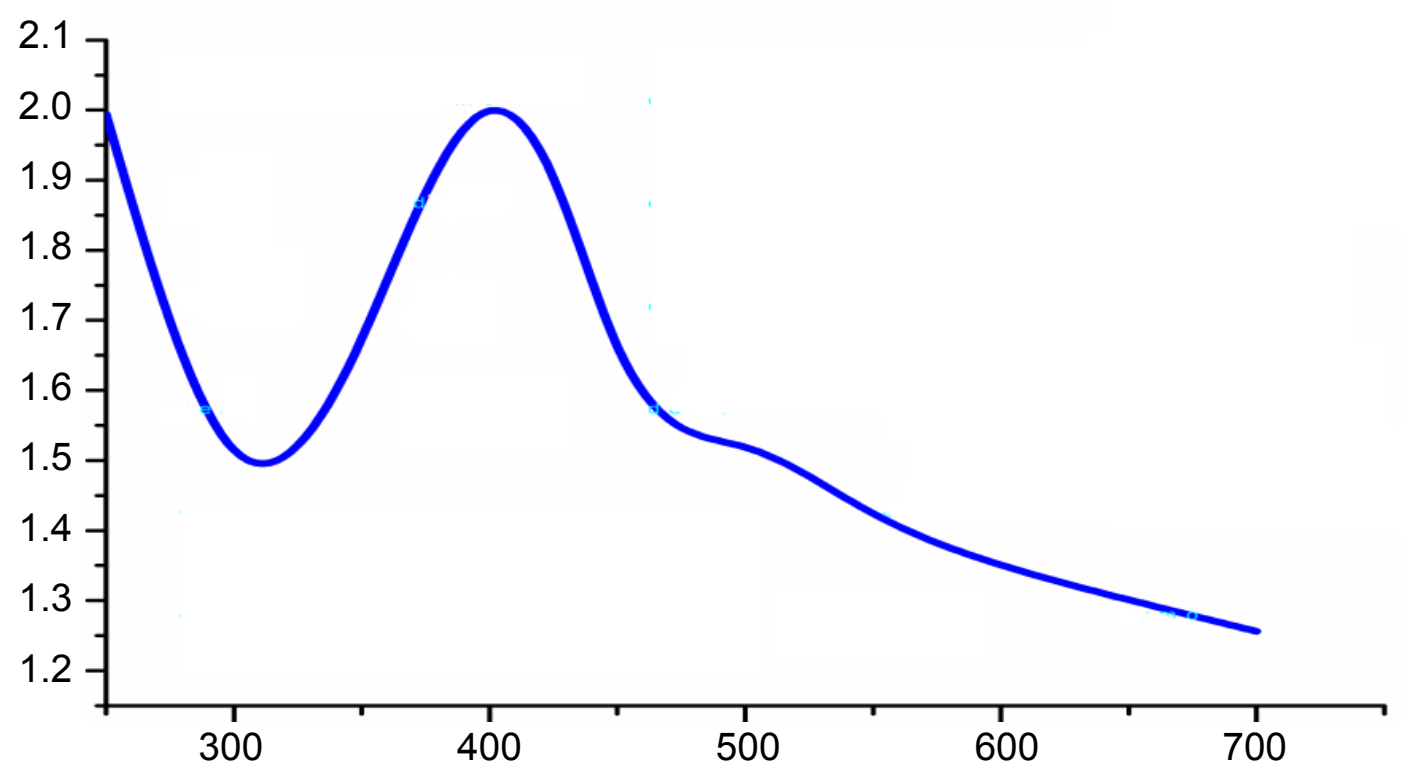

Figure 10: UV-Vis spectra of chitosan silver nanoparticles. 
Citation: Moustafa MT (2019) Comparative Study of Biodegradation and Coagulation of Dairy Effluent by Using Immobilized Microbial Isolates and Chitosane Silver Nano Particles and Production Biodiesel. Ann Microbiol Res 3(1):61-75

\section{UV-Vis Spectroscopy Analysis}

UV-Vis spectroscopic analysis is commonly used method to identify the formation of metal nanoparticles by analyzing the unique optical properties which depends on the size and the shape of the nanoparticles [46]. When $\mathrm{AgNO}_{3}$ was mixed with chitosan solution, $\mathrm{Ag}^{+}$ions could be bound to chitosan macromolecules via electrostatic interactions, because the electron-rich oxygen atoms of polar hydroxyl and ether groups of chitosan are expected to interact with electropositive transition metal cations [47]. Ag nanoparticles were formed by reduction of $\mathrm{Ag}^{+}$using chitosan as both reducing as well as stabilizing agent and the process was accelerated by the use of $\mathrm{NaOH}$. The colour of the solution changed from yellow to brown by $\mathrm{NaOH}$ indicating the formation of Ag nanoparticles [48]. The characteristic brown colour of colloidal silver solution is due to the excitation of surface plasmon vibrations in the nanoparticle and provides a convenient spectroscopic signature of their formation [39]. The UV-Vis spectrum of chitosan-Ag nanoparticle exhibited a strong absorption band at $400 \mathrm{~nm}$ (Figure 10). This is due to the strong surface plasmon resonance (SPR) shown by silver nanoparticles. Similar results were $400 \mathrm{~nm}$ obtained by [15].

\section{Determination of Fatty Acids Profile by GC- FID}

Fatty acids composition FAMEs of the test oleaginous fungal isolates mucor circinelloides in liquid medium molasses of date which were extracted by acid methanolysis during transesterification process of fungal lipids extract to Fatty Acid Methyl Esters (FAMEs) and were determined by GC/ MS. As shown in Figure 11, fatty acid profiles by GC/MS showed the presence of a high fraction of saturated, and monounsaturated fatty acids which is considered a potential feature to indicate the fuel quality of fungal based diesel. Among saturated fatty acids, high amount of palmitic acid (C16:0) and significant amount of stearic acid (C18:0) were observed in the lipid profile of mucor circinelloides. Among monounsaturated fatty acids, oleic acid (C18:1) was shown in the Table 3. Few amounts of capric acid, undecanoic acid and vaccenic acid exhibiting percentage values of $1 \%$ respectively. Fungal oleaginous usually differ from most vegetable oils in being rich in PUFAs (polyunsaturated fatty acids) and hence are mainly exploited for PUFA production [49]. Fatty acids indicated for good biodiesel properties include C14:0, C16:0, C16:1, C18:0, C18:1 and C18:2 [50].

\section{Fatty acids composition of lipid extracted}

The growth and lipid production of oleaginous fungi mucor circinelloides in various molasses waste, Sugarcane bagasse and water hyacinth were studied. By accumulating lipids within a short period of time and growing well on a variety of wastes and inexpensive materials, such as nutritional residues molasses from industry and Sugarcane bagasse and water hyacinth, the oleaginous microorganisms plays a vital role in lowering the cost of fuels [51]. It was found that all the carbon sources used supported the growth and production of lipid to a considerable extent. Various low cost substrate were used which includes molasses, Sugarcane bagasse and water hyacinth. Figures 12 and Figure 13 show the biomass concentration and lipid concentration of fungi grown in different low cost substrate respectively. It was observed that there was an increase in biomass concentration and lipid concentration when the fungi were cultured in media containing molasses as carbon source. The lipid concentration for carbon sources molasses, Sugarcane bagasse and water hyacinth were $34.62 \%, 14.78 \%$ and $9.68 \%$ respectively. It was reported that the increased fungal biomass was due to the increased of reducing sugar content in the culture media [52].

\section{Identification of Fungal Species}

The colony morphology of mycelium by light microscope identified fungus isolate was Mucor coccinellids as shown in

Table 3: Fatty acid composition of extracted total lipids from $M$. circinelloides grown in media containing molasses as carbon sources.

\begin{tabular}{|l|l|}
\hline Fatty acid & Concentration (\%) \\
\hline CAPRIC ACID (C10:0) & $1.57 \%$ \\
\hline UNDECANOIC ACID (C11:0) & $1.40 \%$ \\
\hline LAURIC ACID (C12:0) & $1.96 \%$ \\
\hline MYRISTIC ACID (C14:0) & $3.95 \%$ \\
\hline PALMITOLEIC ACID (C16:1 $\Omega 7)$ & $4.09 \%$ \\
\hline HEPTADECENOIC ACID (C17:0) & $1.04 \%$ \\
\hline STEARIC ACID (C 18:0) & $4.86 \%$ \\
\hline OLEIC ACID (C18:1 $\Omega 9)$ & $35.08 \%$ \\
\hline LINOLEIC ACID (C 18:2) & $9.09 \%$ \\
\hline PALMITIC ACID (C 16:0) & $13.78 \%$ \\
\hline VACCINIC ACID (C18:2 $\Omega 7)$ & $1.04 \%$ \\
\hline GAMMA LINOLENIC ACID (C18:3 $\Omega 7)$ & $18.85 \%$ \\
\hline RUMENIC ACID (C18:2 $\Omega 7)$ & $2.48 \%$ \\
\hline
\end{tabular}

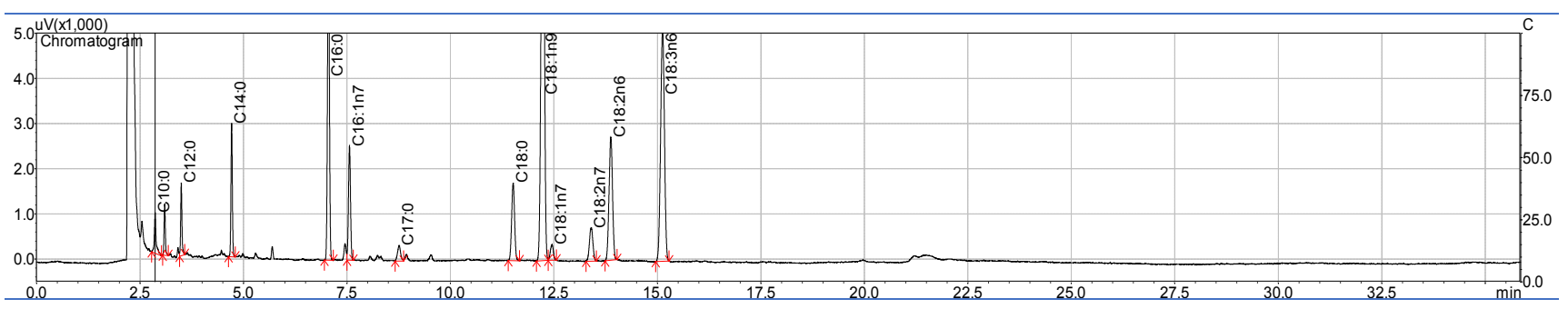

Figure 11: GC chromatogram of fatty acid methyl esters extracted from of mucor circinelloides. 
Citation: Moustafa MT (2019) Comparative Study of Biodegradation and Coagulation of Dairy Effluent by Using Immobilized Microbial Isolates and Chitosane Silver Nano Particles and Production Biodiesel. Ann Microbiol Res 3(1):61-75

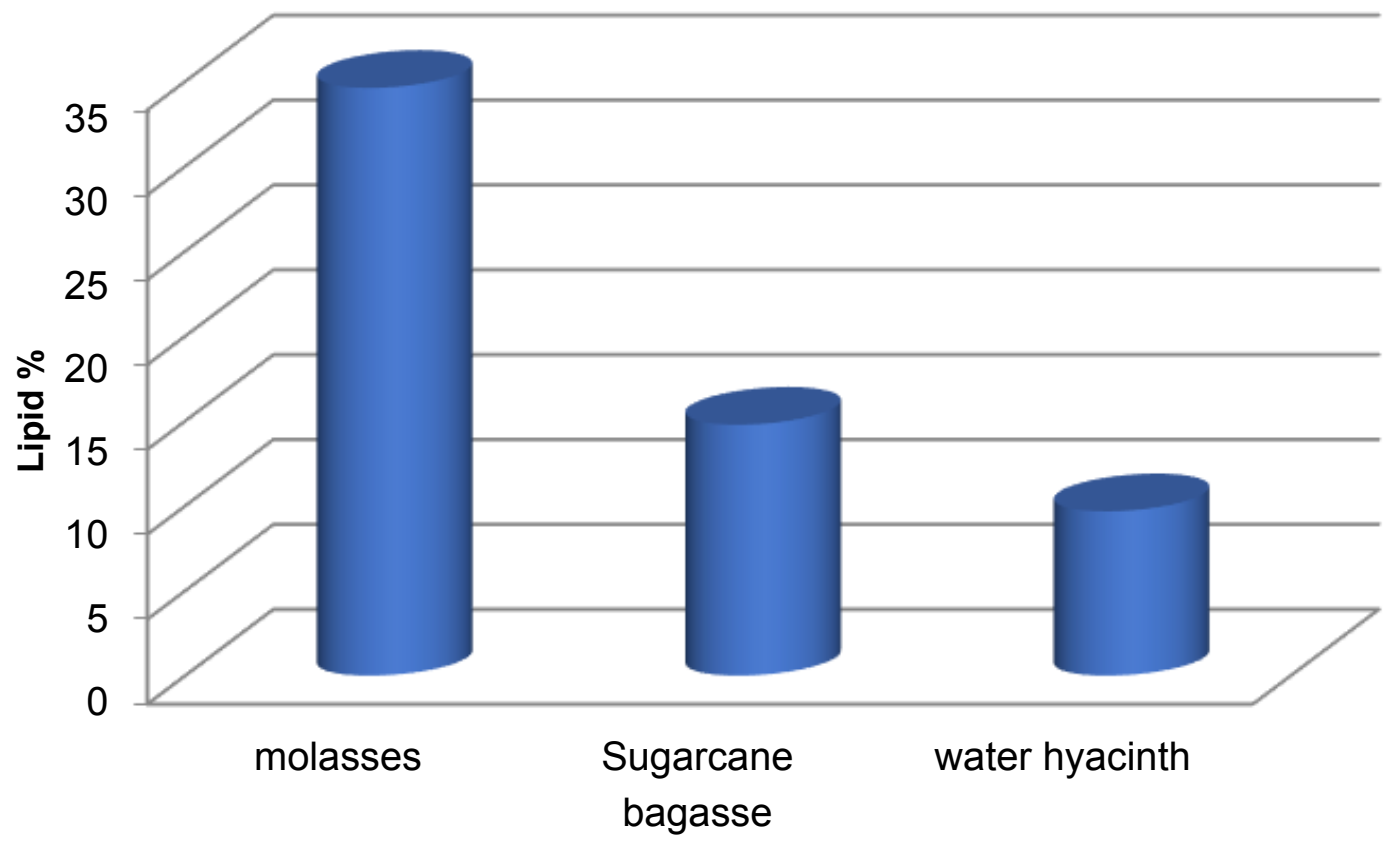

Figure 12: Biomass concentration of fungi grown in different low cost substrate.

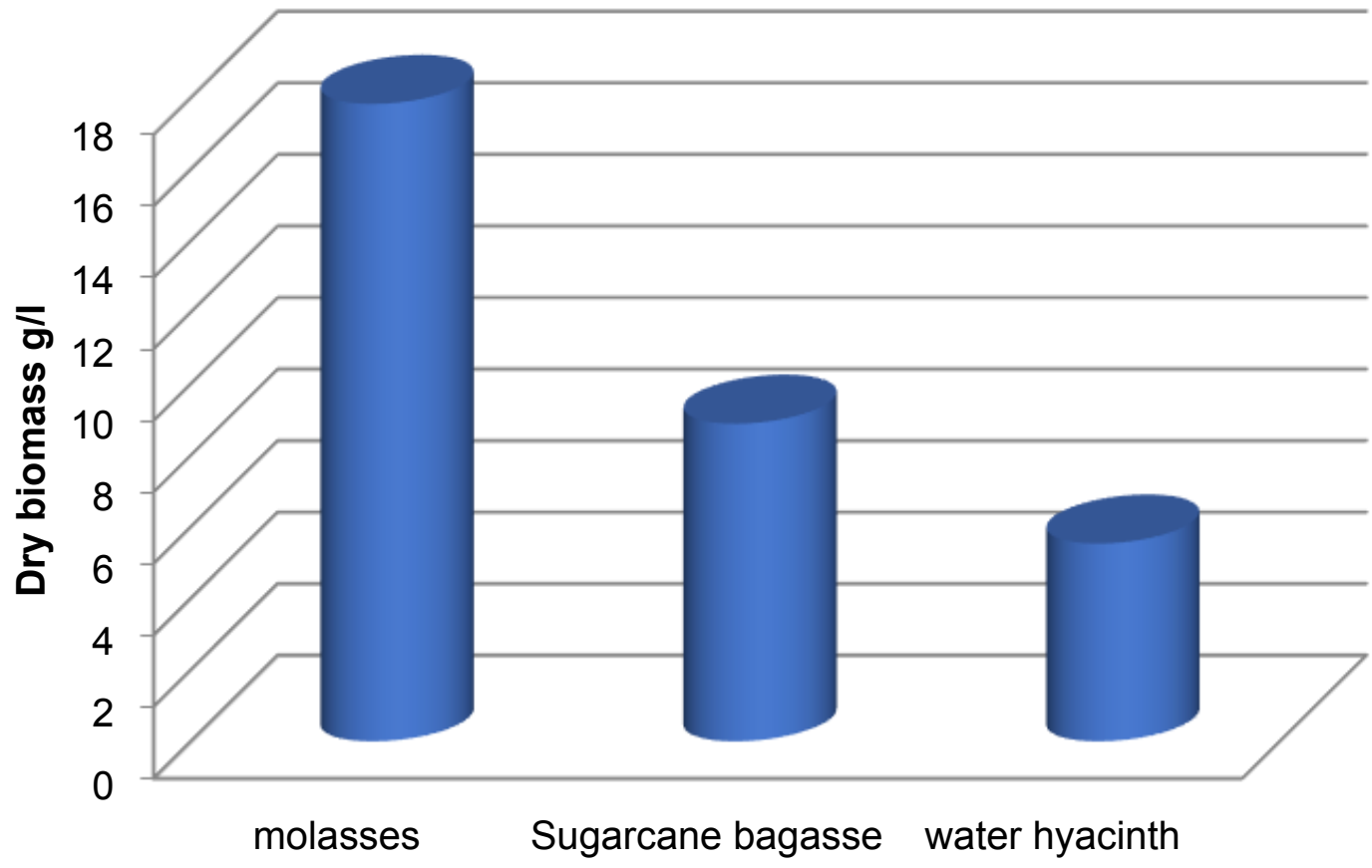

Figure 13: Lipid concentration of fungi grown in different low cost substrate.

(Figure 14). As well as, the $18 \mathrm{~S}$ rDNA gene sequence was applied and confirmed that fungal isolate as Mucor coccinellids (1382 bp) using BLASTn on NCBI and showing the homology sequences with different percent. The nucleotide sequence of Mucor circinelloides containing internal transcribed spacer 1; 5.8S ribosomal RNA gene and internal transcribed spacer 2, complete sequence; and large subunit ribosomal RNA gene, partial sequence. The fungal isolate was submitted on the international NCBI/EMBL/DDBJ/Genbank databases with accession number MF078484.1 as Mucor circinelloides strain MC7001 (www.ncbi. nlm.nih.gov/nuccore/MF078484.1). The neighbor-joining phylogenetic tree, Figure 15 , was constructed with these homologous sequences. The filamentous fungus was identified as Mucor circinelloides belonged to family Mucoraceae.

\section{Conclusion}

The dairy industry is the one of the leading industry in the 


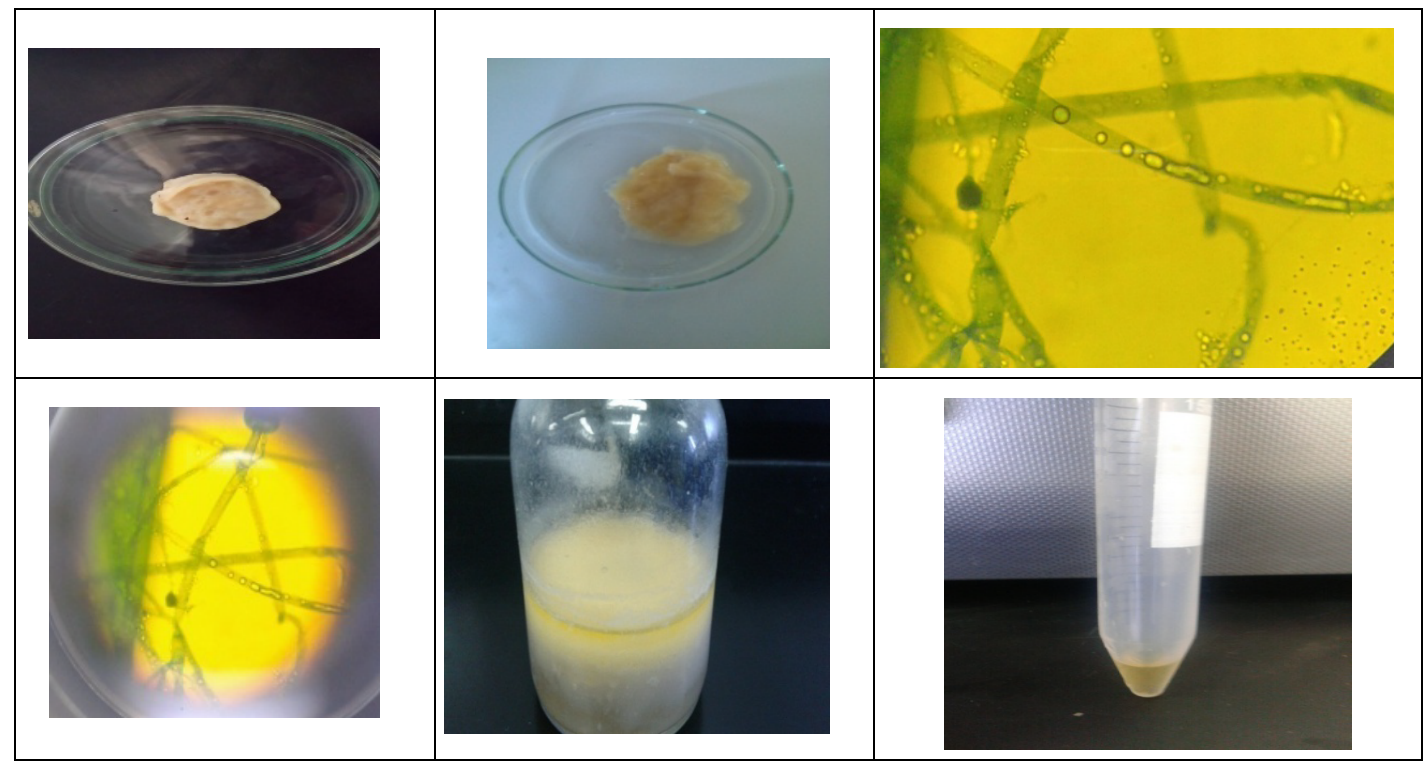

Figure 14: Morphological characteristics of the fungal strain mucor circinelloides observed and photographed under light microscope and extracted mycodiesel.

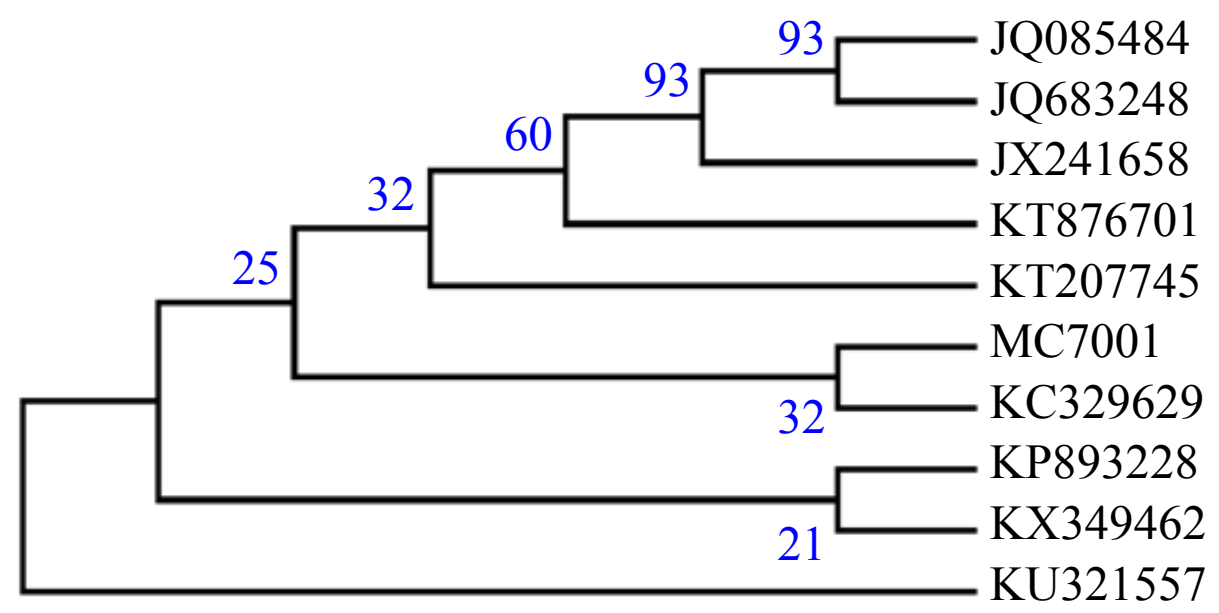

Figure 15: Phylogenetic tree of the mucor circinelloides domain of 18S rDNA gene sequences.

world. It can be concluded that the integrated treatment system designed here was effective for treatment of dairy wastewater by microbial isolates and natural coagulant chitosane. According to the results, fungal isolate is the most effective organisms than bacterial isolate to reduce the COD and BOD concentration more $82 \%$ and $98.6 \%$. These microbial isolates can be efficiently applied for the biological treatment of the dairy effluent treatments. Microbial isolates uses the organics in Wastewater as a food supply so that water pollution threats due to dairy effluents can be reduced through biological methods and this will enable the recycling of water. On using chitosane silver nanoparticles in the pilot unites, it gives $90.3 \%, 82 \%, 98.6 \%$ and $76 \%$ removal efficiencies for TSS, COD, BOD and Ammonia, respectively. Antibacterial effect of chitosan-Ag nanoparticle materials increased with increasing time. $M$. circinelloides can be grown on agricultural wastes it can be used for producing cheap microbial oil and can con- trol environmental pollution. Higher biomass and lipid content was obtained when the filamentous fungi was cultured in the media containing molasses. The present investigation supported that $M$. circinelloides MC7001 can be cultured in molasses as carbon source for biodiesel production. Presence of palmitic (16:0), oleic (18:1), stearic (18:0) and linoleic $(18: 2)$ acids strongly supports that the fungal can be used for the biofuel production. Finally, production of biodiesel at low cost opens the door for replacing fossil fuel and avoiding its environmental, health, and economic problems.

\section{Conflict of Interest}

The authors declare no conflict of interest.

\section{References}

1. Porwal HJ, Mane AV, Velhal SG (2015) Biodegradation of dairy effluent by using microbial isolates obtained from activated 
Citation: Moustafa MT (2019) Comparative Study of Biodegradation and Coagulation of Dairy Effluent by Using Immobilized Microbial Isolates and Chitosane Silver Nano Particles and Production Biodiesel. Ann Microbiol Res 3(1):61-75

sludge. Water Resources and Industry 9: 1-15.

2. Porwal HJ, Mane AV, Velhal SG (2014) Biodegradation of dairy effluent by using microbial isolates obtained from activated sludge. Water Resources and Industry, 1-20.

3. BREF (2006) Integrated pollution prevention and control, Reference document on best available techniques in the food, drink and milk industries. European Commission.

4. Kolhe AS, Ingale SR, Bhole RV, et al. (2009) Effluents of diary technology. Int Res 5: 459-461.

5. Kumar D, Desai K (2011) Pollution abatement in milk dairy industry. Current Pharma Research 1: 145-152.

6. Page LH, Ji-Qin N, Heber A, et al. (2014) Characteristics of volatile fatty acids in stored dairy manure before and afteranaerobic digestion. Biosystems Engineering 118: 16-28.

7. Ganapathy SG, Baskaran R, Mohan PM (2011) Microbial diversity and bioremediation of distilleries effluent. Journal of Research in Biology 3: 153-162.

8. Qasim W, Mane AV (2013) Characterization and treatment of selected food industrial effluents by coagulation and adsorption techniques. Water Resources and Industry 4: 1-12.

9. Shivsharan VS, Wani M, Khetmalas MB (2013) Isolation of Microorganisms from Dairy Effluent. British Microbiology Research Journal 3: 346-354.

10. Janczukowicz W, Zielinski M, Debowski M (2008) Biodegradability evaluation of dairy effluents originated inselected sections of dairy production. Bioresour Technol 99: 4199-4205.

11. Kasture NS (2017) Bioremediation of Nitro-aromatics: An Overview, International Journal of Environment, Agriculture and Biotechnology 2.

12. Hassan MA, Hassan A, Soo Hui L, et al. (2009) Removal of boron from industrial wastewater by chitosan via chemical precipitation. Journal of Chemical and Natural Resources Engineering 4: 1-11.

13. Kumari S, Rath P, Sri Hari Kumar A (2016) Chitosan from shrimp shell (Crangon crangon) and fish scales (Labeorohita): Extraction and characterization. African Journal of Biotechnology 15: 12581268.

14. Sofiane B, Slimane S K (2015) Biosorption of heavy metals by chitin and the chitosan. Scholars Research Library, Der Pharma Chemica 7: 54-63.

15. Thomas V , Yallapu MM, Sreedhar B, et al. (2013) Fabrication, Characterization of Chitosan/Nanosilver Film and Its Potential Antibacterial Application. J Biomater Sci Polym Ed 20: 21292144.

16. Ali A, Mirvaghefi A, Tehrani MR, et al. (2011) Enhancement and Characterization of Chitosan Extractionfrom the Wastes of Shrimp Packaging Plants. J Polym Environ 19: 776-783.

17. Varun TK, Senani S, Jayapal N, et al. (2017) Extraction of chitosan and its oligomers from shrimp shell waste, their characterization and antimicrobial effect. Vet World 10: 170-175.

18. Abu Yousuf, Mozammel Hoque M, Asraful Jahan (2012) Technology and engineering of biodiesel production: A comparative study between microalgae and other nonphotosynthetic oleaginous microbes. International Review of Chemical Engineering 4: 624-628.

19. Liang MH, Jiang JG (2013) Advancing oleaginous microorganisms to produce lipid via metabolic engineering technology. Prog Lipid Res 52: 395-408.

20. Calvey CH, Su YK, Willis LB, et al. (2016) Nitrogen limitation, oxygen limitation, and lipid accumulation in Lipomyces starkeyi. Bioresour Technol 200: 780-788.

21. Bharathiraja B, Sridharan S, Sowmya V, et al. (2017) Microbial Oil - A Plausible Alternate Resource for Food and Fuel, Application. Bioresour. Technol 233: 423-432.

22. Azócar L, Ciudad G, Heipieper H, et al. (2010) Biotechnological Processes for Biodiesel Production Using Alternative Oils. Applied Microbiology and Biotechnology 88: 621-636.

23. Abu-Elreesh GM, Abd-El-Haleem DA (2015) Biodiesel, bioflocculant and biosorbent from the fungal Curvularia sp. strain DFH1. Pelagia Research Library.

24. Soccol CR, Dalmas NCJ, Soccol VT, et al. (2017) Pilot scale biodiesel production from microbial oil of Rhodosporidium toruloides DEBB 5533 using sugarcane juice: Performance in diesel engine and preliminaryeconomic study. Bioresource Technology 223: 259-268.

25. Li Y, Zhao Z, Bai F (2007) High- density cultivation of oleaginous yeast Rhodosporidium toruloides $\mathrm{Y} 4$ in fed-batch culture. Enzyme and Microbial Technology 41: 312-317.

26. Li Q, Du W, Liu D (2008) Perspectives of microbial oils for biodiesel production. Appl Microbiol Biotechnol 80: 749-756.

27. Ramos MJ, Fernández CM, Casas A, et al. (2009) Influence of fatty acid composition of raw materials on biodiesel properties. Bioresour Technol 100: 261-268.

28. Vicente G, Bautistaa LF, Rodrígueza R, et al. (2009) Biodiesel production from biomass of an oleaginous fungus. Biochemical Engineering Journal 48: 22-27.

29. Zhang X, Yan S, Tyagi RD, et al. (2014) Ultrasonication assisted lipid extraction from oleaginous microorganisms. Bioresour Technol. 158: 253-261.

30. Magdum SS. Minde GP, Adhyapak U, et al. (2015) Competence evaluation of mycodiesel production byoleaginous fungal strains: Mucor circinelloides and Gliocladium roseum. International Journal of Energy and Environment 6: 377-382.

31. Boekhout T, Kurtzman CP, O'Donnell K, et al. (1994) Phylogeny of the yeast genera Hanseniaspora (anamorph Kloeckera), Dekkera (anamorph Brettanomyces), and Eeniellaas inferred from partial 26s ribosomal DNA nucleotide sequences. Int J Syst Bacteriol 44: 781-786.

32. Altschul SF, Madden TL, Schaffer AA, et al. (1997) Gapped BLAST and PSI-BLAST: A new generation of protein data basesearch programs. Nucl Acids Res 25: 3389-3402.

33. Kumari S, Rathb PK (2014) Extraction and Characterization of Chitin and Chitosan from (Labeo rohit) Fish Scales. Procedia Materials Science 6: 482-489.

34. Wang LS, Wang CY, Yang C-H, et al. (2015) Synthesis and anti-fungal effect of silver nanoparticles-chitosan composite particles. Int J Nanomedicine 10: 2685-2696.

35. Bligh EG, Dyer WJ (1959) A rapid method of totallipid extraction and purification. Can J Biochem Physiol 37: 911-917.

36. Shin DY, Cho HU, Utomo JC, et al. (2015) Biodiesel production from Scenedesmus bijuga grown in anaerobically digested food wastewater effluent. Bioresource Technology 184: 215-221. 
Citation: Moustafa MT (2019) Comparative Study of Biodegradation and Coagulation of Dairy Effluent by Using Immobilized Microbial Isolates and Chitosane Silver Nano Particles and Production Biodiesel. Ann Microbiol Res 3(1):61-75

37. Slavov AK (2017) General characteristics and treatment possibilities of dairy wastewater - A review. Food Technol Biotechnol 55: 14-28.

38. Shahidi F, Arachchi JKV, Jeon Y (1999) Food application of chitin and chitosans. Trends in Food Science \& Technology 10: 37-51.

39. Guzmán MG, Dille J, Godet S (2009) Synthesis of silver nanoparticles by chemical reduction method and their antibacterial activity. Int J Chem Biomol Eng 2: 104-111.

40. Chatterjee S, Pugaht P (2013) Assessmentof physicochemical parameters of dairy wastewater and isolation and characterization of bacterial strainsin terms of COD reduction. International Journal of Science, Environment 2: 395-400.

41. Zadinelo IV, Santos LD, Cago L, et al. (2018) Adsorption of aquaculture pollutants using a sustainable biopolymer. Environ Sci Pollut Res Int 25: 4361-4370.

42. Qin C, Li H, Xiao Q, et al. (2006) Water solubility of chitosan and its antimicrobial activity. Carbohydrate Polymers 63: 367-374.

43. Bevilacqua A, Corbo MR, Sinigaglia M (2010) Application ofAlternative Food-preservation Technologies to Enhance Food Safety and Stability. Bentham Science Publishers, UAE 207.

44. Dibrov P, Dzioba J, Gosink KK, et al. (2002) Chemiosmotic mechanism of antimicrobial activity of $\mathrm{Ag}(+)$ in Vibrio cholerae. Antimicrob Agents Chemother 46: 2668-2670.

45. Kim JS, Kuk E, Yu KN, et al. (2007) Antimicrobial effects of silver nanoparticles. Nanomedicine 3: 95-101.

46. Ajitha B, Reddy YA, Reddy PS (2015) Green synthesis and characterization of silver nanoparticles using Lantana camara leaf extract. Materials Science and Engineering: C 49: 373-381.

47. Saifuddin N, Nian CY, Zhan LW, et al. (2011) Chitosan-silver Nanoparticles Composite as Point-of-use Drinking Water Filtration System for Household to Remove Pesticides in Water. Asian Journal of Biochemistry 6: 142-159.

48. Shameli K, Ahmad MB, Wan Yunus WMZ, et al. (2010) Synthesis and characterization of silver/polylactide nanocomposites. Proc World Acad Sci Eng Technol 64: 28-32.

49. El-haj M, Olama Z, Holail H (2015) Single cell oil of oleaginous fungi from Lebanese habitats as a potential feed stock for biodiesel. International Journal of Current Microbiology and Applied Sciences 4: 11-34.

50. Schenk PM, Thomas-Hall SR, Stephens E, et al. (2008) Second generation biofuels: High-efficiency microalgae for biodiesel production. Bioenergy Res 1: 20-43.

51. Angerbauer C, Siebenhofer M, Mittelbach M, et al. (2008) Conversion of sewage sludge into lipids by Lipomyces starkeyi for biodiesel production. Bioresour Technol 99: 3051-3056.

52. Jamal P, Tompang MF, Alam MZ (2009) Optimization of media composition for the production of bioprotein from pineapple skins by liquid-state bioconversion. Journal of Applied Science 9: 3104-3109. 